\title{
Investigating comprehensive assessment plans in undergraduate communication studies programs
}

Andrea Celeste Weber

West Virginia University

Follow this and additional works at: https://researchrepository.wvu.edu/etd

\section{Recommended Citation}

Weber, Andrea Celeste, "Investigating comprehensive assessment plans in undergraduate communication studies programs" (2007). Graduate Theses, Dissertations, and Problem Reports. 4348.

https://researchrepository.wvu.edu/etd/4348

This Dissertation is protected by copyright and/or related rights. It has been brought to you by the The Research Repository @ WVU with permission from the rights-holder(s). You are free to use this Dissertation in any way that is permitted by the copyright and related rights legislation that applies to your use. For other uses you must obtain permission from the rights-holder(s) directly, unless additional rights are indicated by a Creative Commons license in the record and/ or on the work itself. This Dissertation has been accepted for inclusion in WVU Graduate Theses, Dissertations, and Problem Reports collection by an authorized administrator of The Research Repository @ WVU.

For more information, please contact researchrepository@mail.wvu.edu. 
Investigating Comprehensive Assessment Plans

in Undergraduate Communication Studies Programs

Andrea Celeste Weber

Dissertation submitted to the College of Human Resources and Education at West Virginia University in partial fulfillment of the requirements for the degree of Doctor of Education

In

Educational Leadership

Elizabeth Jones, Ph.D., Chair

Ernest Goeres, Ph.D.

Matthew M. Martin, Ph.D.

Scott A. Myers, Ph.D.

Richard T. Walls, Ph.D.

Department of Advanced Educational Studies

Morgantown, West Virginia

2007

Keywords: Comprehensive Assessment, Program Review, Communication Studies 


\author{
ABSTRACT \\ Investigating Comprehensive Assessment Plans \\ In Undergraduate Communication Studies Programs
}

\begin{abstract}
Andrea Celeste Weber
Outcome assessments of academic programs have become increasingly critical in recent years. A continuous process formed to "monitor and improve student learning," true assessment serves to focus institutions of higher education on student learning (Allen, 2004, p. 5). It is vital to understand and explore current assessment practices in departments of communication studies to ensure and enhance the quality and future of education in the field. This study represents an initial attempt at establishing a baseline of assessment practices utilized within departments of communication studies. The results exhibit the extent to which assessment is being used for continuous improvement of communication studies undergraduate programs across various institution types. Assessment processes, methods, utilization and communication of assessment results and differences in practice between Carnegie Classifications were explored, with encouraging results. Respondents from communication studies departments were fairly progressive with regard to their views and uses of assessment. However, assessment efforts still need to be expanded. Further research on best practices of assessment in communication studies departments across all institution types could reveal strategies for enhancing the assessment culture throughout the field.
\end{abstract}




\section{TABLE OF CONTENTS}

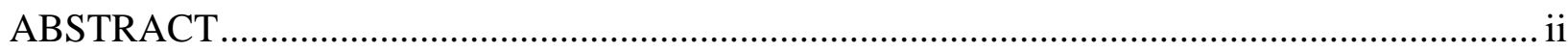

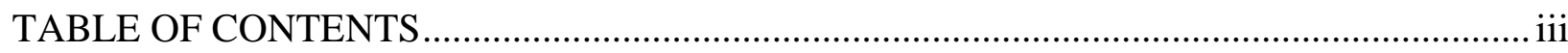

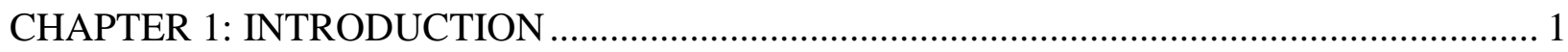

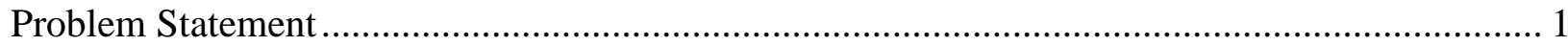

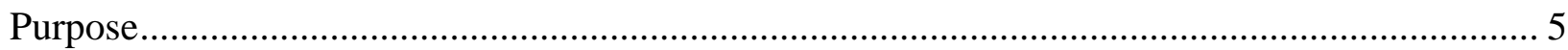

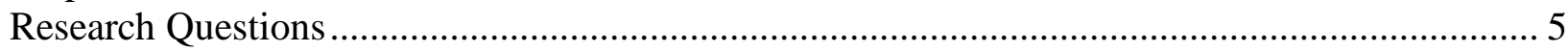

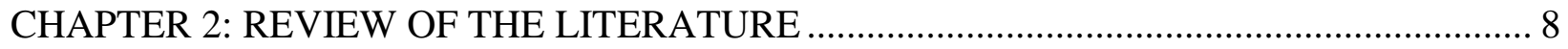

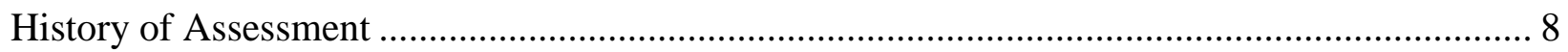

Comprehensive Program Assessment ................................................................................... 9

Creating Meaningful Learning Outcomes ................................................................... 10

Creating Opportunities to Achieve Outcomes …………........................................... 16

Assessing Student Learning ………………………….............................................. 17

Incorporating Assessment Results ............................................................................. 21

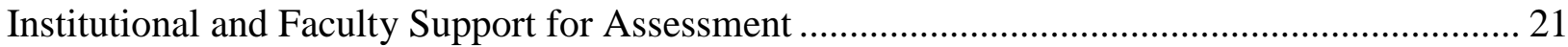

Discipline Specific Assessment Research Studies...................................................................... 24

Communication Studies Assessment Literature …………......................................................... 26

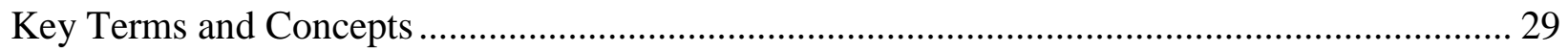

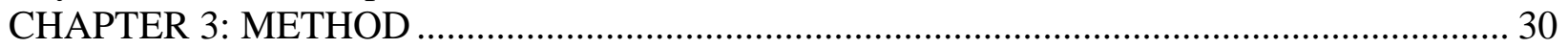

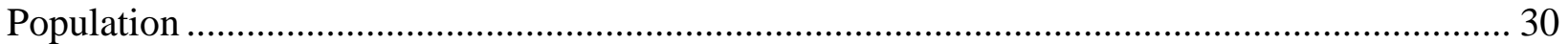

Survey Design and Procedures for Data Collection ................................................................ 32

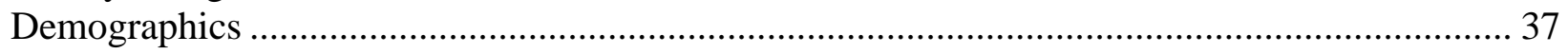

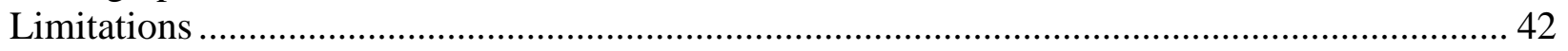

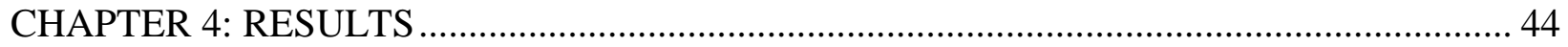

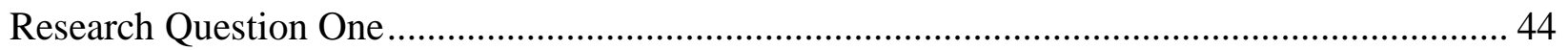

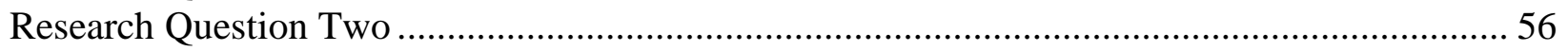

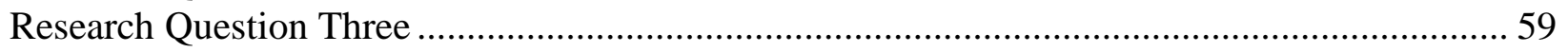

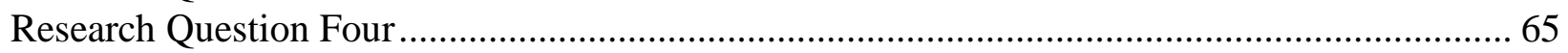

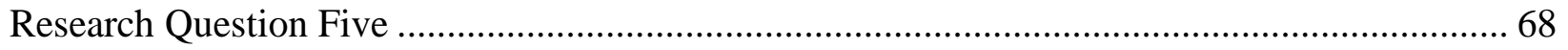

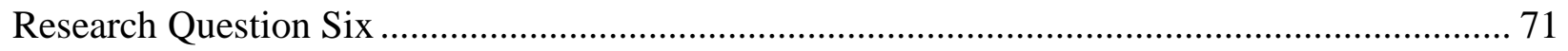

CHAPTER 5: CONCLUSION AND IMPLICATIONS …………........................................... 75

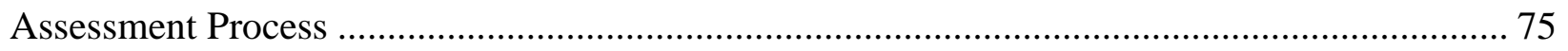

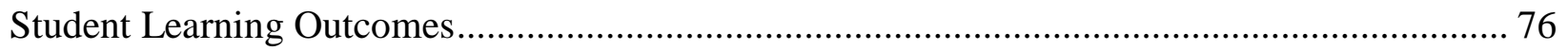

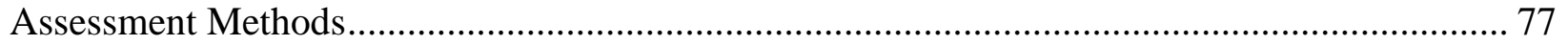

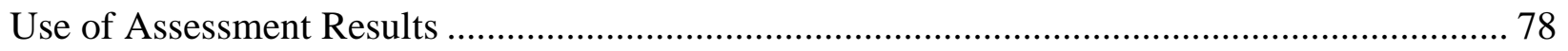

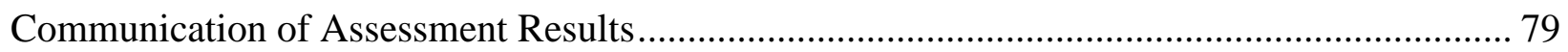

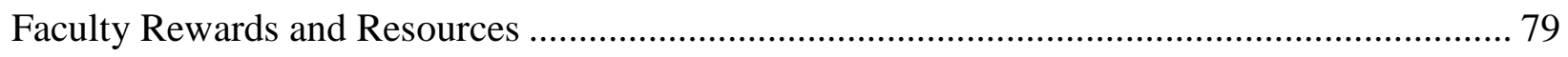

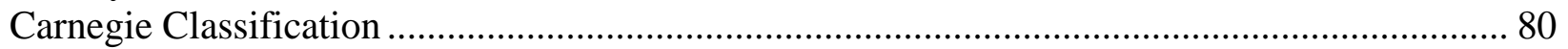

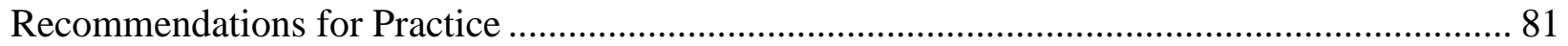

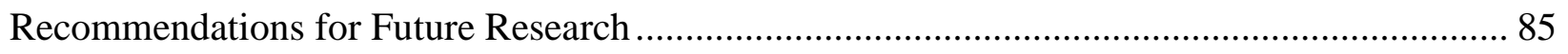

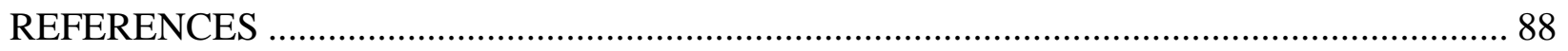

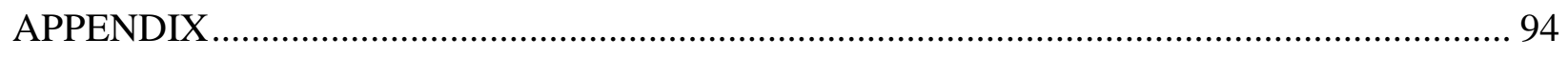

Appendix A: Pilot Study Cover Letter...................................................................................... 95

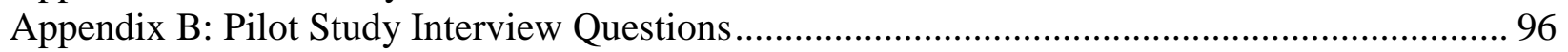


Appendix C: Cover Letter to Survey Participants .............................................................. 97

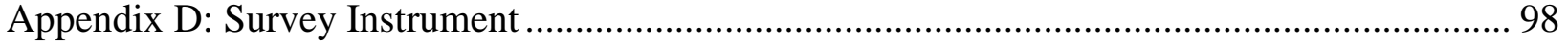




\section{CHAPTER 1: INTRODUCTION}

\section{Problem Statement}

Outcome assessments of academic programs have become increasingly critical in recent years. A continuous process formed to "monitor and improve student learning," true assessment serves to focus institutions of higher education on educational outcomes (Allen, 2004, p. 5). Assessment is operationalized by Huba and Freed (2000) as a four-step process that includes establishing learning goals, presenting opportunities to achieve these goals, assessing student learning, and implementing assessment findings into the curriculum to improve student learning. More specifically, the first step encompasses the creation of intended learner outcomes in a clear, measurable form. It is then necessary to provide opportunities to ensure students accomplish the intended learning outcomes. For assessment to occur, these outcomes should then be continuously collected, examined, measured, and interpreted to determine whether the intended learning outcomes are being met. Finally the results must be utilized to advance and develop student learning. All four steps must be present for a comprehensive assessment to transpire (Huba \& Freed, 2000; Suskie, 2004). This chapter will discuss research on current assessment practices, demonstrating the need for quality program-level assessments and developing a context for the study.

Regional accrediting organizations, mandated by the federal government, require all institutions to provide direct evidence that they are achieving their mission. Institutions of higher education, therefore, must provide direct evidence that students are achieving the learning goals established by the institutions (Suskie, 2004). According to Peterson and Einarson (2001), college and university administrators have attempted to fulfill this mandate by instituting policies that require department and college-level assessments. However, at research and doctoral level 
institutions especially, there have been few attempts to examine assessment plans and processes for quality assurance (Peterson \& Einarson, 2001). Little in the way of professional development has been provided to administrators, faculty, and student affairs personnel. Peterson and Einarson (2001) stated that departments are not aware of the proper procedures for assessment, nor do they understand the purposes and benefits of incorporating assessment into the program curriculum. Furthermore, almost no connection to student assessment practices and faculty evaluation and reward policies has been established (Peterson \& Einarson, 2001). Departments, therefore, see little value in implementing comprehensive assessment plans outside of institutional or accreditation mandates (Peterson \& Einarson, 2001).

According to Mintzburg (1979), institutional administrators at research institutions are responsible for accountability of student learning outcomes to external constituencies; yet departments, and in turn, professors, are typically self-governing with regard to curricula and teaching. In other words, although administrators are accountable for student learning outcome achievement, professors shoulder the responsibility of ensuring that students are achieving these intended learning outcomes. At the department level, however, research and graduate education are encouraged, resulting in little emphasis on undergraduate student assessment (Peterson \& Einarson, 2001).

Hatfield (1999) explains that for many academic departments, the mandated assessment from administration has involved little thought or effort. To complete the minimum requirements for accreditation or to satisfy administrations' requests, program assessment consists of a review process every three to five years. While this does constitute an effort, according to Hatfield (1999), granting an isolated glance at a department's operation, usually in the form of standardized tests, is not an accurate view of the functioning of that department. The culture of 
most academic departments does not encourage in-depth, continuous assessment for improvement. At the program level, assessment protocols are viewed as excessive and unnecessary, adding to the responsibilities of an already overwhelmed department chair (Hatfield, 1999). However, faculty ownership of assessment is crucial for success (Gray, 2002). Faculty are responsible for teaching and learning, which is the purpose of comprehensive assessment.

While assessment began as a process that anticipated accountability, accreditation requirements now emerge as the presiding stimuli for many institutions' assessment efforts. Peterson and Vaughn (2002) stated that although undergraduate education is addressed in a majority of institutional missions, accreditation was the highest-rated purpose for engaging in assessment. Internal improvement appears to be a very minor consideration for engaging in assessment. There is little leadership support through mission or governance activities for assessment. Administrators are accountable to external constituencies, but faculty are autonomous with regard to scholarship and teaching (Peterson \& Einarson, 2001).

Peterson and Einarson (2001) also investigated the use and impact of student assessment. They found that the majority of institutions do little to monitor student assessment information, and in turn, do not utilize this data to influence decision making, providing little evidence of any impact that current assessment has on students, faculty, or external constituencies (Peterson \& Einarson, 2001). In other words, while many departments may have clear intended learner outcomes, provide opportunities for students to achieve outcomes, and actually measure those outcomes, assessment findings are not being evaluated to assess and improve student learning. According to Suskie (2004), all four steps of the assessment process must be present for a comprehensive assessment. 
These findings show that the value of the assessment process is dramatically underestimated. Institutions have been investing time, money and energy on continuing to require assessments from which they and their constituencies are not benefiting.

Implementing a comprehensive, four step assessment plan, rather than sporadic, isolated reviews can be beneficial to both programs and students. Institutions can benefit immensely from implementing an initiative for continuous improvement (Hatfield, 1999). According to Peterson and Einarson (2001), student assessment researchers affirm that "conducting assessment for internal purposes, strong leadership support, a combination of centralized and decentralized governance structures, and ongoing evaluation of assessment efforts are important means by which institutions can effectively support and benefit from student assessment” (p. 656). Comprehensive assessment allows for the strengthening of student services and satisfaction, improved retention and enrollment, morale building, and enrichment of development and funding initiatives (Huba \& Freed, 2000).

Student assessment literature signifies the vital role that institutional climate and culture play in the promotion and utilization of student assessment to improve academic program performance (Peterson \& Einarson, 2001). However, the nature of research institutions challenges the value of current assessment mandates. Because departments and faculty in large research universities act autonomously, self-governing their scholarship and teaching, assessment directives are considered more of an inconvenience and burden to a department than a service. As indicated by Peterson and Einarson (2001), administrative policy and procedure directs the implementation of assessment practices at the departmental level. Faculty resent administrative mandates requiring change and extra work (Hatfield, 1999). 
To influence the culture of institutions so that faculty embrace assessment practices, changes must take place at the departmental level. According to Mintzburg (1979), change implemented at the departmental level is more likely to be accepted by professionals. If a culture of comprehensive assessment is introduced to departments at the faculty level, it is more likely to take root and grow within that department.

\section{Purpose}

"Higher education is beyond the question of whether assessment should exist and is now asking how it can yield greater benefits for students and society" (Erwin \& Wise, 2002, p. 67). The purpose of this study was to gather descriptive data on current departments of communication studies assessment practices at different institutions. The analysis of data collected determines the extent to which assessment is being used for continuous improvement of communication studies undergraduate programs across institutions. This study establishes a baseline of assessment practices in undergraduate communication studies programs for future investigations. This baseline encourages further research into model programs of assessment and areas of strengths and weaknesses of assessment practices in the field of communication. Finally, examining successful assessment practices in undergraduate communication studies programs pinpoints specific processes, including faculty or departmental rewards that encourage comprehensive program assessment over time.

\section{Research Questions}

1. To what extent are communication studies departments implementing comprehensive undergraduate program assessment plans?

a. At the program level, what student learning outcomes are expected from undergraduates? 
b. To what extent are student learning outcomes being measured? How are they measured?

c. To what extent are assessment results utilized to make program improvements? How are they used to make improvements?

2. To what degree are assessment results communicated and to what audiences? How are results communicated?

3. What institutional resources are provided for undergraduate communication program faculty to develop and implement assessment? How are faculty rewarded for assessment efforts?

4. Is there a statistically significant difference in the extent to which communication studies undergraduate programs are implementing their assessment plans that vary according to different institutional types (Carnegie Foundation for the Advancement of Teaching, 2000)?

a. Doctoral/Research Universities-Extensive and Intensive

b. Master's Colleges and Universities I and II

c. Baccalaureate Colleges-Liberal Arts and General

d. Associates Colleges

5. Is there a statistically significant difference in the extent to which undergraduate communication studies departments communicate their results to different audiences that vary according to different institution types (Carnegie Foundation for the Advancement of Teaching, 2000)?

a. Doctoral/Research Universities—Extensive and Intensive

b. Master's Colleges and Universities I and II

c. Baccalaureate Colleges-Liberal Arts and General 


\section{d. Associates Colleges}

6. Is there a statistically significant difference in the extent to which resources are available to undergraduate communication studies departments for program assessment that vary according to different institution types (Carnegie Foundation for the Advancement of Teaching, 2000)?
a. Doctoral/Research Universities-Extensive and Intensive
b. Master's Colleges and Universities I and II
c. Baccalaureate Colleges-Liberal Arts and General
d. Associates Colleges

This chapter outlined the background of the problem for the purpose of this study. The next chapter will discuss the history of the assessment movement and review relevant literature pertaining to assessment at the program level. The four steps of assessment (Huba \& Freed, 2000) will be discussed in detail as they relate to this research. Following a review of relevant literature, the methodology for this study will be presented including the study's population, sample, data collection, analysis, and limitations. Results of this study will be discussed, addressing each of the research questions. The final chapter will address conclusions and implications for practice and future research. 


\section{CHAPTER 2: REVIEW OF THE LITERATURE}

This literature review first considers the history of the assessment movement. Comprehensive program assessment is then defined as a four-step process, detailing each of the four steps. Relevant research in program assessment is reviewed, addressing institutional support of faculty development, case studies in specific departments, research on assessment in specific disciplines, and the state of assessment in communication studies.

\section{History of Assessment}

In the mid-1900's, higher education institutions were established in record numbers. According to Cook (1997), the 1950's through the mid 1970's were a “Golden Age” of higher education institutions, where federal funds were plentiful and university budgets were unlimited. In 1975, the "Golden Age" of flowing federal funds turned into an "Era of Uncertainty." The 1970's resulted in a drastic change in the economic health of the country, and in turn, higher education institutions. Universities were in serious financial trouble as federal funds became scarce. Suddenly these institutions had to rely on private donations in order to survive (Cook, 1997).

Not only were institutions of higher learning in financial crisis, but an educational dilemma was occurring as well. The expansion of universities allowed for a more diverse student-body population. Administrators and faculty struggled to adjust their curricula and teaching methods to accommodate a larger and more diverse student population (Ewell, 2002).

Prior to the 1970's, the value of a college education was assumed (Huba \& Freed, 2000). Once federal resources became scarce, institutions began relying on private funding to maintain and cultivate their standards. Institutions were struggling with both the need for resources and adapting to the changing make-up of the student population. 
Suddenly, external constituencies (e.g., government, corporations) began questioning the value of higher education, and with the need for private funds, institutions became accountable to their constituencies. Higher education institutions needed to adapt to the changing needs of their students, with fewer resources, in order to maintain standards of higher education (Huba \& Freed, 2000).

Colleges and universities found themselves under a myriad of pressures from external constituencies to provide evidence of their effectiveness (Cheng, 2001). Legislators desired accountability for state and federal funds (Redmond, 1998). Corporate America was academe's largest consumer and they wanted quality graduates, making university recruiting dependent upon job placement success (Redmond, 1998). Ewell (2002) stated that for universities to receive federal funds as well as private donations from both individuals and corporations, and stay competitive with similar institutions, universities were obligated to produce evidence that justified their educational practices. By 1990, more than half of the United States required examination and assessment of learning outcomes in public colleges and universities (Ewell, 2002).

\section{Comprehensive Program Assessment}

Faculty conducting comprehensive program assessment view the examination and improvement of student learning as an ongoing process. The results from program assessments can be utilized to continuously improve student learning through program and course improvements based on program assessment (Allen, 2004). Through creating intended learning outcomes, measuring learning and implementing assessment findings into the curriculum, a continuous process of monitoring and improving student learning is created. 
This continuous process involves four steps. First, clear, explicitly stated program outcomes must be created. Second, opportunities must be provided for students to achieve those learning outcomes. Third, direct and indirect measures should be utilized to assess student learning of the intended learning outcomes. Finally, the results of the assessment must be incorporated into the curriculum to improve student learning.

The American Association for Higher Education (AAHE, 1992) proposed nine principles of good practice for assessing student learning. Relevant principles will be incorporated into the four specific steps, mentioned above, necessary for comprehensive program assessment (Suskie, 2004). The following paragraphs will discuss each of these four steps in detail, addressing the AAHE principles that correspond with each step.

\section{Creating Meaningful Learning Outcomes}

The first step in creating a comprehensive program assessment involves the creation by faculty of statements regarding expectations of student learning. Gray (2002) states that educational outcomes should be specific, measurable, and able to be directly observed. These outcomes are often called behavioral objectives. These clear, explicit behavioral objective statements typically detail what a graduate of an undergraduate program should know and be able to do upon commencement. Meaningful assessment requires this step to guide faculty in the planning and implementation of a comprehensive program assessment (Suskie, 2004).

According to the AAHE, the first principle of good practice for assessing student learning begins with educational values. That is, intended learning outcomes should meaningfully reflect the departmental and institutional goals. Outcomes must measure significant, important information relevant to the program field and the goals of the institution. 
The American Association of Higher Education states (1992, para. 7),

“Assessment.....begins with issues of use and illuminates questions that people really care about." Creating student learning outcomes that are relevant to students, potential employers, administrators, or parents is essential. Student learning outcomes must be related to issues that are important to the discipline and can easily be applied to the real world.

The good practice of assessment requires obvious, concrete purposes (AAHE, 1992 para. 3). Therefore, learning outcomes should state what faculty want their students to learn in tangible terms. It is essential that these outcomes are clear, understandable and visible to all of a program's constituents. Prospective students, current students, faculty, administrators and staff should be acutely aware of a program's objectives. Faculty, students, parents, administrators, employers and the general public should take part in the planning and implementation of assessment according to the sixth principle of good practice for assessing student learning (AAHE, 1992, para. 6).

Clear intended learning outcomes provide students with knowledge about faculty intentions. With concrete knowledge of a program's learning outcomes, potential students understand the objectives of a potential major, providing them with the resources to make an informed choice when deciding on a major discipline. Current students with a clear understanding of program learning outcomes are able to appropriately focus their education and career goals, resulting in an environment that promotes student learning of meaningful criteria. Intimate knowledge of these outcomes allows faculty to have the resources to plan and implement a curriculum that addresses the stated objectives. Explicitly stated outcomes encourage faculty to utilize curricula to address these outcomes. Professors can use the 
objectives to create learning experiences to garner the results they expect from their students, resulting in student achievement at the end of a course or program (Huba \& Freed, 2000). In sum, "clarity about outcomes is seen as a powerful means of ensuring that learning occurs, because it can help faculty and students decide how they should use their time and energy" (Gray, 2002, p. 52). The following paragraphs will discuss the creation of intended learning outcomes using cognitive, affective and psychomotor domains of learning.

\section{Domains of Learning}

According to the National Communication Association's Guidelines for Developing a Departmental Assessment (2005), program objectives should encompass three domains of student learning: student knowledge (cognition), skills (behavior), and attitudes (affect). The following paragraphs will discuss each of these domains.

\section{Cognitive Domain}

The cognitive domain of learning emphasizes the acquisition of knowledge. Bloom (1956) created a framework for categorizing cognitive educational objectives. Anderson et al. (2001) recently revised this taxonomy. Their revision included an additional cognitive objective and revised the taxonomy to include a knowledge dimension. This added dimension divides the concept of knowledge into four categories; factual knowledge, conceptual knowledge, procedural knowledge, and meta-cognitive knowledge, with meta-cognitive knowledge considered the highest knowledge dimension.

According to Anderson et al. (2001), a student learning objective can be broken down into two parts. The objective's verb represents the cognitive process dimension (e.g., remember, understand, apply, analyze, evaluate, and create). The objective's noun represents the knowledge 
dimension (e.g., factual, conceptual, procedural, meta-cognitive). Table 1 illustrates the revised taxonomy.

Table 1

The Taxonomy Table

The Knowledge

Dimension

Remember Understand Apply Analyze Evaluate Create

Factual

Knowledge

Conceptual

Knowledge

Procedural

Knowledge

Meta-

cognitive

Knowledge

Note. From A taxonomy for learning, teaching, and assessing: A revision of Bloom's Taxonomy

of Educational Objectives (p. 28), by Anderson, L. W., Krathwohl, D. R., Airasian, P. W.,

Cruikshank, K. A., Mayer, R. E., Pintrich, P. R., Raths, J., \& Wittrock, M. C. (Eds.), 2001, New

York: Longman.

Anderson et al. (2001) defined the six categories of the cognitive process dimension as follows (p. 31):

1. Remember-Retrieve relevant knowledge from long-term memory (recognize, recall).

2. Understand-Construct meaning from instructional messages, including oral, written, and graphic communication (interpret, exemplify, classify, summarize, infer, compare, explain).

3. Apply-Carry out or use a procedure in a given situation (execute, implement). 
4. Analyze-Break material into constituent parts and determine how parts relate to one another and to an overall structure or purpose (differentiate, organize, attribute).

5. Evaluate-Make judgments based on criteria and standards (check, critique).

6. Create-Put elements together to form a coherent or functional whole; reorganize elements into a new pattern or structure (generate, plan, produce).

The major types of the knowledge dimension include:

1. Factual Knowledge-The basic elements students must know to be acquainted with a discipline or solve problems in it (terminology, specific details or elements).

2. Conceptual Knowledge-The interrelationships among the basic elements within a larger structure that enable them to function together (classifications, categories, principles, generalizations, theories, models, structures).

3. Procedural Knowledge-How to do something, methods of inquiry and criteria for using skills, algorithms, techniques, and methods (subject specific skills, specific techniques and methods, criteria for determining use of appropriate procedures).

4. Meta-cognitive Knowledge-Knowledge of cognition in general as well as awareness of knowledge of one's own cognition (strategic knowledge, cognitive tasks, appropriate contextual and conditional knowledge, self-knowledge) (Anderson et al, 2001, p. 29).

\section{Behavioral Domain}

Skills acquisition with regard to student learning encompasses the ability of students to perform observable behaviors. This psychomotor domain implies cognitive or affective learning demonstrated through observable behaviors (NCA, 2005). According to Suskie (2004), skills include thinking (e.g., analysis, evaluation), performance (e.g., physical skills) or interpersonal 
skills (e.g., effectively work in and lead groups, communicate with individuals from various backgrounds, listen). Huba and Freed (2000) describe the psychomotor or skills domain as "the development of muscular skills and neuromuscular coordination” (p. 112).

\section{Affective Domain}

The third learning domain encompasses student affect, or the feelings or attitudes about knowledge or skills obtained in the other two domains (NCA, 2005). Affective learning is the establishment of favorable learner attitudes about subject matter. According to Suskie, “attitudinal goals include appreciation; becoming more aware of one's own values, attitudes, and opinions and their evolution and maturation; integrity; character; and enjoying and valuing learning" (p. 86). Few resources are available for assessing affective domains of learning, Anderson et al. (2001) suggested the lack of resources on the affective domain of learning occurs because "nearly every cognitive objective has an affective component" (p. 258). The addition of a meta-cognitive component to the revised cognitive taxonomy "in some respects bridges the cognitive and affective domains" (p. 259).

According to Huba and Freed (2000), all three learning domains must be addressed by intended learning outcomes. At basic levels, knowing, doing and feeling may be measured separately. However, at advanced levels, students must be able to merge all three domains of learning (Morreale, Rubin \& Jones, 1998). The integration of new material with existing knowledge is required for all learning, and therefore all three domains are vital for comprehensive program assessment (Huba \& Freed, 2000).

Once faculty articulate student learning objectives, it is necessary to provide opportunities for students to achieve those outcomes. The second step of a comprehensive 
assessment program, the creation of opportunities to achieve student learning objectives, will be discussed in the next section.

\section{Creating Opportunities to Achieve Outcomes}

The second step in a comprehensive assessment plan is for faculty to create experiences to ensure students can achieve the intended learning objectives (Suskie, 2004). According to the AAHE (1992), “Assessment requires attention to outcomes but also and equally to the experiences that lead to those outcomes" (para. 4). Creating intended learning outcomes is meaningless without opportunities for students to achieve those objectives (Suskie, 2004).

The AAHE suggests that "assessment is most effective when it reflects an understanding of learning as multidimensional, integrated, and revealed in performance over time" (1992, para. 2). Huba and Freed (2000) suggested that the curriculum should be planned as a "set of interrelated courses and experiences that will help students achieve the intended learning outcomes" (p. 13). Allowing students multiple ways to demonstrate success of the intended learning outcomes creates a more suitable environment for comprehensive assessment. Students learn more when various modes of teaching are utilized in the classroom. These modes entail learning through lecture, class discussion, active participation, and learning by teaching others. Students actively involved in learning develop a deeper understanding of content (Newman, Couturier \& Scurry, 2004).

Not only is it necessary for students to have a variety of learning opportunities, it is vital for all students to have the opportunity to achieve all stated goals. Each stated learning outcome must be associated with at least one opportunity for all students to achieve that outcome. Various opportunities should be offered for students to demonstrate their abilities at an assortment of levels. Each intended learning outcome must be examined to determine curricular activities that 
address that outcome. Examining experiences that may lead to intended learning outcomes is an essential part of a comprehensive assessment plan (Huba \& Freed, 2000).

Once experiences are created that lead to intended learning objectives, it is necessary to then measure student learning of the objectives. This will be discussed in the following section.

\section{Assessing Student Learning}

Allen (2004) and Huba and Freed (2000) stated the importance of utilizing assessment measures that are both reliable and valid. For an assessment measure to be considered valid, it must "yield information to guide learning [the assessment task] must ask for a demonstration of the actual achievements faculty want students to do well” (Huba \& Freed, 2000, p. 225). Allen (2004) stated a "valid assessment of a learning objective tells [instructors] how well students have mastered that objective, and it should provide useful, formative information" (p. 62).

Reliable assessments yield consistent conclusions. Longer assessments, assessments of abilities and objectively scored procedures tend to be more reliable than shorter assessments, assessments of opinions or personalities and subjectively scored assessments (Allen, 2004). Both reliability and validity are crucial for comprehensive program assessment.

\section{Assessments Techniques}

Academic departments have developed a variety of ways to assess student learning. Numerous studies have been conducted to explore assessment practices in academic departments. According to Palomba and Banta (1999), both direct and indirect assessments are necessary to demonstrate student achievement of intended learning outcomes. These data may come from course-embedded assessments or outside of class assessments.

Direct measures of student learning include evidence that indicates a student's ability to think critically and use knowledge to "directly reveal the very abilities" stated by the program 
learning objectives (Huba \& Freed, 2000, p. 12). Direct assessment measures include ill-defined problems (i.e., a task that requires students to address an issue or problem that does not have a specific answer, similar to issues they may encounter in the real world), performance assessments, a final exam (Allen, 2004), or activities that require subjective judgment (Huba \& Freed, 2000). Portfolios provide direct evidence of student learning by encouraging students to think meta-cognitively, and allow for diverse student experiences (Allen, 2004). Essentially, direct assessments require students to demonstrate their use of knowledge rather than declare their perceptions of their knowledge.

Many academic programs utilize indirect measures of assessment. Indirect measures illustrate an individual's (i.e., student, former student, employer) perception of student learning (Allen, 2004). This may take the form of self-report measures including senior, graduate or employer interviews or surveys.

Surveys as indirect assessment methods have many strengths including flexibility, minimal expense, and the ability to track opinions across time and explore trends. However, surveys provide indirect evidence of student learning, may be biased and inaccurate, and their validity is dependent on the quality of questions and responses (Allen, 2004).

Interviews are another example of an indirect assessment that is flexible and can provide insights into the reasons for beliefs. Interviews allow for immediacy between the interviewer and interviewee, and interviewers may prompt respondents to provide detailed explanations (Allen, 2004). However, this process may be time consuming, and results may be influenced by poor interviewing skills, intimidation of interviewees, and the validity of the questions and the analysis of results. While this model has many benefits, including the triangulation of interview data, it is still not a direct measure of student learning. According to Huba and Freed (2000), 
indirect measures are not the best indicators of complex, applied, real world abilities, so they should be combined with direct measures of student learning.

Again, in order to accurately measure and assess student learning, it is necessary to utilize both direct and indirect measures. However, as evidenced in many studies, multi-dimensional assessment measures are not typical. The following paragraphs will discuss recent literature on academic programs' intended measurement of student learning.

\section{Examples of Direct and Indirect Assessments}

In 1988, Banta and Schneider attempted to determine the usefulness of faculty developed exit examinations as assessments. They concluded that measurement specialists were needed to ensure that items were appropriate. Final exam questions were found to be too narrow to use for assessment purposes. They provide evidence of student learning, but may be unreliable due to their local development. In addition, creating and scoring effective exams take skill and time. Invariably, utilizing a single measure to examine student learning is not an effective means of assessment (Banta \& Schneider, 1988).

Aitken completed an assessment study in 1994 in the Department of Communication at the University of Missouri. The program incorporated student portfolios as an end of program assessment. However, consistency with the evaluation protocol and coordination of field professionals created some difficulties. A reliable quantitative method of portfolio evaluation was found to be an issue with this type of assessment.

As evidenced in the aforementioned studies, both indirect and direct methods of assessment present many challenges. Single, isolated assessment methods are not an accurate portrayal of the achievement of student learning. Final exam questions are narrow and singledimensional with regard to student learning (Banta \& Schnieder, 1998). Alumni surveys, while 
they do provide useful information, focus on student satisfaction rather than actual learning (Wilson \& Plutsky, 1999). Aitkin's (1994) utilization of student portfolios as a measure of student learning was unable to provide clear, quantitative data on student learning.

To combat these problems, Aitken and Neer (1993) used multiple assessment methods to assess the undergraduate program at the University of Missouri at Kansas City. Direct and indirect methods were utilized and included a communication competency measure, portfolios, interviews and instruction analysis throughout the undergraduate program. The 1993 study discusses a measure developed to determine communication competencies of students throughout their Communication Studies undergraduate program. Distributed to students prior to entering the program and in the middle of the program, results provided information about student's cognitive foundations of communication competencies to faculty, allowing faculty to adapt course content and motivation techniques to strengthen student's communication competencies. Results from the study inspired changes in the Communication Studies undergraduate curriculum. This study incorporates the third and fourth elements of a comprehensive program assessment. Aitken and Neer utilized assessment methods to determine student learning, and then incorporated their assessment findings into the curriculum.

To summarize, Gray (2002) illustrated the importance of reliable and valid assessment measures by stating, "criteria for determining the quality of evaluation methods is that they are authentic and consistent with the learning to be documented and that they conform to prevailing norms set by professional authorities within a given field" (p. 54). The next section will discuss the fourth step in a comprehensive assessment plan, incorporating assessment results into the curriculum. 


\section{Incorporating Assessment Results}

According to Suskie (2004), assessment results that are not examined and incorporated into the curriculum are "a waste of time" (p. 300). Using assessment results for continuous improvement is the final step in a comprehensive assessment plan. Faculty examine results generated by assessment measures in this step to obtain insights into actual student learning in

order to make "informed decisions about needed program changes" (Huba \& Freed, 2000, p. 15).

To gain various perspectives on how student learning can be improved through curricular changes, it is again vital to involve all constituents: faculty, students, parents, administrators, employers and the general public, according to the sixth principle of good practice for assessing student learning (AAHE, 1992, para. 6). Different viewpoints may provide additional insight into why certain opportunities may result in student learning while others do not.

\section{Institutional and Faculty Support for Assessment}

The previous sections discuss the process of comprehensive assessment, including the role of faculty in the assessment process, from formulating student learning objectives and creating experiences that achieve those outcomes to communicating results of assessment. According to Gray (2002), faculty ownership of assessment is crucial for success.

Lopez (1999) researched institutions accredited by the North Central Association of Colleges and Schools to determine barriers to assessment. She found that two primary reasons for lack of comprehensive assessment programs include problems engaging faculty and failure to provide funding for faculty support of assessment efforts. Lopez stated that many faculty were "antagonistic, fearful or passive" when asked to incorporate assessment into their programs (p.9). According to Hatfield (1999), assessment protocols tend to be seen by faculty as excessive and 
unnecessary, adding to the responsibilities of an already overwhelmed department chair (Hatfield, 1999) and busy faculty (Allen, 2004).

Lopez (1999) stated that "in order for assessment to become an integral component of campus culture, faculty need to recognize its potential value, be committed to its inclusion in the regular on-going processes of their institution, accept ownership and responsibility and participate fully in all its components" (p. 9). Allen (2004) affirmed that faculty are usually aware of gaps in student learning, "but these notions are often anecdotal in nature and not systematically addressed" (p. 14). Assessment can help faculty discover, in concrete terms, actual learning outcomes. Assessment provides evidence of what students are learning or not learning, allowing faculty to make deliberate decisions to guide instruction and curriculum and make the argument for new innovations (Allen, 2004).

Three barriers to faculty involvement in the assessment process have been identified by Lopez (1999). Misconceptions about assessment, negative reactions to "measuring" learning, and lack of skills needed to conduct comprehensive assessments have all been found to hinder the assessment process at institutions. Lopez (1999) has identified faculty development as the "primary solution to problems in faculty participating in assessment" (p. 17).

Once the institution itself is committed to assessment efforts (Suskie, 2004), assessment practitioners concur that institutional leaders must support and encourage faculty assessment efforts (Allen, 2004). To engage faculty in the assessment process, Suskie (2004) stated that assessment should be framed as teaching and learning tools. It is essential for faculty to establish ownership of intended student learning outcomes, encouraging responsibility from the beginning of the process. 
Offering faculty and administrators numerous opportunities to learn about the value of assessment has been a successful method of involving faculty in the assessment process at institutional and departmental levels (Lopez, 1999). Institutions have found that bringing in guest chair and faculty consultants from other departments who have successfully incorporated assessment in their own programs have assisted resistant departments in creating their own assessment plans (Lopez, 1999).

Allen (2004) stated there is a need for faculty rewards and incentives to encourage comprehensive assessment practices at institutions of higher learning. Suskie (2004) suggested faculty rewards may include relief from less critical responsibilities, assistance with mundane assessment related tasks, minimal paperwork, and the provision of resources and support for efforts. According to Lopez (1999) incentives may specifically include providing funding to faculty to participate in assessment conferences, or awarding faculty grants for designing and implementing assessment activities.

This section documented the necessity of institutional support of faculty assessment efforts in order for program assessment to be successful. The next section will review assessment research in specific disciplines. 


\section{Discipline Specific Assessment Research Studies}

In addition to researching assessment in specific departments and assessment at the institutional level, researchers have also explored program assessment in specific disciplines. The Engineering, Physician Assistant programs, and the Maryland Cooperative Extension have been examined to determine a baseline of assessment practices in those specific disciplines (Bentlejewski, 2004; McKenzie, 2002; Shipman, 2004).

Engineering faculty throughout the country were studied by McKenzie (2002) to determine if capstone experiences for accredited engineering programs effectively measured student learning outcomes. He found that faculty were concerned about student knowledge of program objectives. A discrepancy was found between the student learning outcomes faculty felt were necessary for capstone students versus the outcomes actually measured by the capstone experience. Faculty also indicated that they could benefit greatly from workshops on creating clear student learning objectives.

Physician Assistant (PA) Educator assessments were studied by Shipman (2004). He surveyed 133 PA program directors across the nation to examine programmatic assessments in Physician Assistant programs. Shipman found that PA programs emphasize student learning outcomes. However, while assessment start-up costs were plentiful, there was a lack of funding to encourage continuous assessment practices. Survey responses indicated that over half of respondents did not have fully developed or fully implemented assessment programs. Moreover, $66 \%$ of PA faculty did not receive an incentive for participating in assessment development. Faculty that are rewarded for assessment development receive external incentives such as commendation from administrators and consideration for the promotion and tenure process (Shipman, 2004). PA Program Directors indicated that intrinsic rewards for faculty assessment 
development include spending time with colleagues. Overall, results indicated that there is a need to formalize the assessment process within Physician Assistant programs. In addition, faculty incentives for development in assessment are also necessary to fully develop assessment plans and programs.

Bentlejewski (2003) examined existing beliefs and practices of faculty on course, program, and institutional assessment within the Maryland Cooperative Extension. A survey distributed to Maryland Cooperative Extension faculty examined faculty views on, and practices of, assessment. The Bentlejewski study focused on creating intended learner outcomes, creating learning experiences based on the intended learner outcomes, measuring student learning, and utilizing assessment results to improve student learning.

Bentlejewski found that faculty believed in the benefits of assessment for planning and making changes to improve future courses. Faculty also recognized challenges associated with assessment. Bentlejewski found that although faculty demonstrate an understanding of the uses of assessment, they did not feel that their colleagues or their administration valued assessment. Other challenges identified by faculty in the Bentlejewski study included lack of training in appropriate methods of assessment and reliability and validity of assessment measures.

With regard to actual assessment practices, Bentlejewski (2003) concluded that Maryland Cooperative Extension Faculty were effectively creating intended learning outcomes. However, faculty did not utilize direct or indirect assessment to measure student learning. Instead, faculty focused on measuring teaching skills and learner reactions rather than assessing actual student learning. 


\section{Communication Studies Assessment Literature}

Recent decades have shown a tremendous transformation and growth in the field of communication studies as an academic discipline (Craig \& Carlone, 1998). Craig and Carlone demonstrated this growth by examining trends in books and serials in the field of communication studies as well as statistics on degrees granted. They found that the growth of bachelor's degrees granted in communication studies increased 534\% between 1967 and 1993. This exceeds the growth in overall bachelors' degrees granted (increase of $84 \%$ ) by more than six times (Craig \& Carlone, 1998). This tremendous growth reinforces the need to examine communication studies programs' effectiveness in higher education.

According to Morreale et al. (2000), communication skills are vital for obtaining and maintaining career advancement. Employers consistently identify intercultural, group, interpersonal, oral and written communication skills as basic needs required of their employees. Due to the central need of all students to acquire communication competencies, the study of communication should be central on college campuses.

Allen (2002) discussed issues related to accountability, assessment and change in general education as a concern for departments of communication due to their important role in general education at most institutions. She concluded that the communication curriculum is accountable to both general education objectives and outcomes and outcomes within communication programs. Allen (2002) emphasized the need for valid and reliable assessment instruments to test specific learning objectives.

Clark (2002) discussed the need within the field of communication to examine instructional practices and particularly assess learning outcomes. Members of the National Communication Association, according to Clark, show their interest in instructional practices by 
the large number of subscribers to communication journals dedicated to teaching. In addition, external pressures for accountability emphasize the importance of creating student learning outcomes in order to measure and justify learning effectiveness. Clark stressed the necessity to "control our own destiny than have others impose procedures on us, and the best way to do this is to have well-developed designs and measures in place for doing so" (p. 297).

Clark (2002) stated the importance of identifying learning outcomes as the first step to comprehensive assessment (Huba \& Freed, 2000). She expresses concern at the lack of welldeveloped instruments for pursuing research on many aspects of communication attitudes, knowledge and skills that communication professionals recognize as important. According to Clark, communication professionals need to discover the enduring outcomes of their programs as well as their real world outcomes. The field must identify attitudes and behaviors students should exhibit in the professional world.

Allen (2002), Clark (2002) and Shelton, Lane and Waldhart (1999) all point to the importance of assessment in communication studies programs. However, limited research has examined assessments in communication studies programs in recent years. Comprehensive research on assessment practices in communication departments was conducted by Hay in 1992. Examining trends in assessment processes in communication departments, Hay focused on the status of assessment on campus, ratings on the importance of assessment, oral communication in general education, sources of information on program effectiveness and faculty involvement in assessment. Results indicated that course evaluations were the most frequent method for gathering information about outcomes of study in the field. Additionally, alumni, employer, graduate school and exit interviews were also cited as sources of information. Many respondents 
indicated that their department was in need of assistance for developing measures or starting on the assessment process.

Hay (1992) discussed the results of the study, expressing concern at the widespread use of course evaluations and alumni surveys as the primary form of data collection for determining educational outcomes. Additionally, Hay mentioned that only about $30 \%$ of departments had defined goals or objectives. Finally, Hay called for communication studies departments to prioritize assessment in order to improve educational quality.

Most additional studies on assessment in communication studies programs have been limited to single case studies of academic departments. Since the 1992 Hay survey, there has been no comprehensive overview of the general state of assessment in undergraduate communication studies programs in the United States today.

The previous paragraphs discussed the necessary components of a comprehensive assessment plan including the development of student learning objectives, the creation of opportunities for students to achieve those objectives, the assessment of student learning and finally the incorporation of assessment findings into the curriculum. Discipline specific studies on comprehensive assessment were reviewed, and the state of assessment in the field of communication studies was discussed. The following chapter will discuss the methods used in this study to examine current assessment practices in undergraduate programs in communication studies. 


\section{Key Terms and Concepts}

1. Assessment: "Assessment is the process of gathering and discussing information from multiple and diverse sources in order to develop a deep understanding of what students know, understand, and can do with their knowledge as a result of their educational experiences; the process culminates when assessment results are used to improve subsequent learning" (Huba \& Freed, 2000, p. 8).

2. Assessment Steps (For program assessment): Faculty develop learning objectives, create opportunities for students to achieve those objectives, measure student learning of objectives and incorporate findings into the curriculum (Huba \& Freed, 2000).

3. Behavioral Objectives: "the outcome of learning using concrete action words; they describe what students can do after they've learned the material” (Suskie, 2004, p. 77).

4. Continuous Improvement: the culmination of assessment when results are used to improves subsequent learning (Huba \& Freed, 2000).

5. Direct Measure of Assessment: Measure that demonstrates student achievement of a learning objective (Allen, 2004).

6. Ill-Defined Problems: assessment task that requires students to address an issue or problem that does not have a specific answer, similar to issues they may encounter in the real world (Huba \& Freed, 2000).

7. Indirect Measure of Assessment: Measure that illustrates perception of learning objective achievement (Allen, 2004).

8. Intended Learning Outcomes: "describe the kinds of things that students know or can do after instruction that they didn't know or couldn't do before” (Huba \& Freed, 2000).

9. Portfolio: Student reflection of learning objective achievement through compilation of work. 


\section{CHAPTER 3: METHOD}

This study utilized quantitative methods to determine the status of assessment in undergraduate communication studies programs. Department chairs of undergraduate communication studies programs were surveyed to assess their utilization of the four steps of comprehensive assessment (Huba \& Freed, 2000), differences in assessment planning and implementation across the various types of institutions, faculty rewards and incentives, and institutional support of assessment (Carnegie Foundation for the Advancement of Teaching, 2000). As evidenced in the previous chapter, little research has been conducted on assessment in undergraduate programs within communication studies.

This study gathered descriptive information about current assessments being used in order to determine communication studies assessment practices and establish a baseline for further study. For the purposes of this study, assessment is operationalized by Huba and Freed (2000) as a four-step process that includes establishing learning goals, presenting opportunities to achieve these goals, assessing student learning, and implementing assessment findings into the curriculum to improve student learning.

\section{Population}

While it began as part of the first institutions of higher education in the United States, communication studies has only in the last 100 years separated from it's roots in English to become an independent department in higher education institutions (Friedrich \& Boileau, 1999). Today's departments of communication studies vary in their college locations (e.g., Arts \& Sciences, Social Sciences, Humanities, Fine Arts) and their titles (e.g., Mass Communication, Journalism, Communication Studies, Speech Communication). These variations are exemplified in the numerous specializations of communication professionals (e.g., Family, Health, 
Intercultural, Instructional, Mass, Organizational, Political, Public address, Theater, Rhetoric). However, the common thread shared by all scholars in the field of communication studies is the study of "communicative behavior with the dual goal of (a) understanding the structure, patterns, and effects of human communication and (b) facilitating a higher quality of communication both for individuals and for society" (Friedrich \& Boileau, 1999, p. 8).

Many communication professionals and communication departments are members of the professional association, the National Communication Association. The National Communication Association (NCA) is a non-accrediting "scholarly society" that "promotes effective and ethical communication... supports the communication research, teaching, public service and practice of a diverse community of scholars, educators, administrators, students, practitioners, and publics" (NCA, 2004).

Because membership in NCA does require a yearly fee, not all communication studies departments are members of the association. To generalize the results of this study to all communication departments in the United States, both NCA member communication departments and non-member communication departments were asked to participate in this study. NCA recognizes both member and nonmember departments as belonging to the field of communication studies.

Just as not all communication studies departments are members of NCA, not all individual members of NCA are affiliated with a department of communication studies. Due to the variety of interests of communication professionals, scholars studying communication reside in departments of theatre, humanities, women's studies, political science, education, and English. The National Communication Association Directory (2003) lists 1,944 affiliated departments (which may or may not include individual NCA faculty members regardless of departmental 
membership) in 1,530 institutions. Within these 1,944 affiliated departments, 353 institutions are departmental members. Institutions with more than one departmental listing include departments of communication along with departments of theatre, humanities, English, public relations, and political science. To limit the scope of this study, only 1056 departments listed by the National Communication Association with undergraduate academic programs entitled "communication" were surveyed. The department chair at each of the 1056 institutions received the survey.

In addition to restricting participants by department, distribution of surveys was limited to departments with specific Carnegie Classifications (Carnegie Foundation for the Advancement of Teaching, 2000). Departments granting doctoral and master degrees as well as colleges granting primarily undergraduate baccalaureate degrees and associates degrees were surveyed. These included Doctoral/Research Universities-Extensive, Doctoral/Research UniversitiesIntensive, Master's Colleges and Universities I, Master's Colleges and Universities II, Baccalaureate Colleges-Liberal Arts, and Baccalaureate Colleges-General, Baccalaureate/Associate's Colleges and Associate's Colleges. Specialized Institutions (e.g., theological seminaries, technical institutions) as classified by the Carnegie Foundation for the Advancement of Teaching were not included in this survey (Carnegie Foundation for the Advancement of Teaching, 2000). Surveys were coded by institution type prior to distribution of the survey.

\section{Survey Design and Procedures for Data Collection}

Descriptive, quantitative research methods were utilized to complete this study. Descriptive research, "captures and displays a graphic picture of a situation-expressed in numbers" (Locke, Silverman \& Spirduso, 1998, p. 128). 
The instrument employed for this study is a combination of Lusher's Accounting Program Assessment Questionnaire (2005) and Shipman's Survey of Internal Programmatic Assessments Implemented by Physician Assistant Educators (2004) consisting of closed-ended questions including Likert type, continuous and checklist items drawn from assessment literature (Allen, 2004; Huba \& Freed, 2000; Palomba \& Banta, 1999; Suskie, 2004) (see Appendix D). Items referring to the Assessment Process (questions 1 through 8), Assessment Activities (questions 32 through 48), Assessment Results (questions 49 through 56), Assessment Audiences (questions 57 through 65), and Dissemination of Assessment Results (questions 66 through 73) were adapted from Lusher (2005). Respondents choose the most appropriate response ranging from very often (1) to never (5). The introduction of the survey includes the definition of assessment employed for this study. In addition, the researcher included demographic questions.

Items adapted from Shipman (2004) include those items requesting information on Institutional Resources for Assessment (questions 74 through 78), Faculty Development (questions 79 through 85), Faculty Incentives for Assessment (questions 87 through 95) and Faculty Benefits of Assessment (questions 96 through 106). The instrument utilized for this survey identified the frequency of certain activities. Therefore, respondents chose the most appropriate response ranging from very often (1) to never (5). Also, the categories Intrinsic and Extrinsic Rewards under Faculty Incentives for Assessment were collapsed into one category entitled Benefits.

A pilot study surveying six communication studies department chairs across various Carnegie Classifications about their departmental assessment practices was conducted in order to assess the "content validity.....and to improve questions, format, and the scales" (Creswell, 2003, p. 158) of the instrument following approval from West Virginia University's Institutional 
Review Board (IRB) for the Protection of Human Subjects in the summer of 2005. Pilot study participants were contacted in advance to determine their willingness to participate. This pilot study was conducted to increase the survey's internal validity (Locke, Silverman \& Spirduso, 1998).

Pilot study participants received a cover letter and survey instrument. Following distribution of the pilot study survey, the researcher contacted all six participants via telephone to discuss their suggestions regarding the survey instructions, items, or other issues of concern. Feedback from the pilot study was utilized to make three changes to the cover letter and instrument. First, respondents indicated the cover letter should emphasize the benefit this study would provide to the field of Communication Studies. Therefore, the researcher included a specific example of how the results may be utilized to improve assessment practices in the field. The cover letter stated "this research will provide useful information for faculty and administrators to maximize the results of assessment practices......the extent to which direct assessment methods are used to enhance Communication Studies curricula." Second, it was also recommended that IRB approval be emphasized in the second paragraph. Third, it was suggested that a summary of the survey results should be offered to participants interested in the study findings.

Additionally, pilot study participants suggested a few minor changes be made to the survey. Typographic errors were revealed and changed based on pilot study feedback. It also was recommended that respondents should be able to mark their answers in boxes rather than circles. Answer boxes were altered to make it easier for respondents to check their response rather than darken a circle, which is a more awkward and time consuming method of response according to the pilot study participants. A few questions were reworded to clarify the intent of the item. The 
order of item two was revised to move from general to specific and an additional response was added to this item to encompass all possible process stages. Item 21 was altered to address how informed students are upon entering the program rather than prior to entering the program. The phrase "into the curriculum" was added to item 25 to clarify the intent of the question. The time frame on item 86 was narrowed to reflect the number of faculty development sessions on assessment over the past year to more accurately reflect recent assessment efforts.

Significant changes were also made to a few of the survey instructions. It was suggested that the directions at the beginning of each section indicate survey responses should reflect departmental assessment practices rather than institutional assessment practices. It was mentioned that the wording regarding levels of assessment (departmental or institutional) was vague and confusing. Pilot study participants suggested that terms used in survey instructions for each section be clarified. Consequently, student learning outcomes were described prior to items 7 through 30. In addition, it was suggested that adequate space be placed on the survey for respondents to add comments and supplementary information to item 78 .

Finally, it was recommended that direct and indirect methods be measured more specifically on the survey. Originally, direct and indirect methods of assessment were measured using a Likert scale ranging from very often to never. Pilot study participants recommended utilizing temporal items, resulting in more useful, specific responses. For example, under direct methods, the survey was altered so respondents were asked to indicate the years in which each method was used for assessing student learning. Direct measures of assessment explore student achievement of learning objectives (Allen, 2004), and are therefore more accurately measured by examining students progression throughout college. Participants were able to select from the 
following; Freshman, Sophomore, Junior and/or Senior years. They were also able to indicate if that type of direct method was utilized every year of school or not at all.

Indirect measures of assessment illustrate student, alumni and other constituent perceptions of achievement of learning objectives, and are therefore easily measured chronologically. The pilot study feedback resulted in changes to the survey so respondents were able to indicate whether they utilized particular methods every semester, once a year, every two to three years, every three to four years, every five to six years, or never. Implementing the changes recommended by the pilot study participants allowed for more precise, accurate survey responses.

The revised survey, along with a cover letter and self addressed stamped envelope was mailed to all 1,056 undergraduate communication department chairs following the pilot study in October, 2005. The cover letter explained the purpose of the study, introduced the primary researcher, and thanked the participants for their time and commitment to complete the enclosed survey. Participants were asked to answer a series of demographic questions describing their institution, program and department. Finally, participants were asked to complete and return the survey in the self-addressed stamped envelope provided in the survey packet by November 11, 2005.

A follow-up bulletin was posted on the Communication Research and Theory Listserve (CRTNET) prior to the survey deadline in November. According to the National Communication Association (2005), CRTNET is a free, daily Listserve that serves as an information vehicle for communication studies professionals to post and receive information on position openings, announcements, grant opportunities, articles and other relevant information pertaining to the 
field of communication. The notice was addressed to Communication Studies chairs, and served as a reminder to complete and submit the assessment surveys prior to the end of the year.

\section{Demographics}

Eighty-three department chairs completed and returned the survey prior to the deadline. Following the CRTNET reminder, an additional fifteen viable surveys were returned by January 15, 2006. A total of 98 department chairs completed and returned the survey resulting in a $9.2 \%$ response rate. As noted in Table 2, respondents were from both public and private institutions. Of those responding to the survey, $17.3 \%$ were from doctoral level institutions, $9.1 \%$ from doctoral extensive institutions and $8.1 \%$ were from doctoral intensive institutions. Masters level institution respondents encompassed $42.8 \%$ of respondents, $35.7 \%$ from Masters I institutions and $7.1 \%$ from Masters II institutions. Of the total respondents in this study, $20.4 \%$ of Communication Studies chairs responded from Bachelor level institutions, 8.1\% from BA Liberal Arts, 12.2\% from BA General institutions, 18.3\% of participants responded from Associates institutions (see Table 2).

The highest mean of full-time faculty (18.7) was reported from Doctoral Level Extensive institutions. The highest mean of part-time faculty was reported from Doctoral Level Intensive institutions. Associates institutions reported the lowest full-time faculty mean (4.4) but indicated a higher part-time faculty mean (7.8) than Masters Level II and Baccalaureate institutions.

Doctoral Level Extensive institutions reported the highest mean graduates per year (118.1), and Baccalaureate General institutions reported the lowest mean graduates per year (19.9). Associates institutions reported a mean of 112.1 students graduating with Associates degrees in Communication Studies per year. 
Additional demographic questions requested information on departmental membership in both national and regional associations. Fifty-five (56\%) of respondents indicated that they were members of the National Communication Association (NCA). Four (4\%) respondents indicated they were members of the Eastern Communication Association (ECA), 11 cited membership in the Central States Communication Association (CSCA), 8 were members of the Southern States Communication Association (SSCA), and 10 indicated membership in the Western States Communication Association (WSCA). Many NCA members were also members of their respective regional associations, although some regional association members were not members of the National Communication Association. 


\section{Table 2}

Respondent Demographics

\begin{tabular}{|c|c|c|c|c|c|c|c|c|c|c|c|c|c|c|c|}
\hline \multirow{3}{*}{$\begin{array}{l}\text { Carnegie } \\
\text { Classification }\end{array}$} & & \multirow{2}{*}{\multicolumn{2}{|c|}{$\begin{array}{c}\text { \# of } \\
\text { Responses }\end{array}$}} & \multirow{2}{*}{\multicolumn{2}{|c|}{$\begin{array}{c}\text { Public } \\
\text { Institutions }\end{array}$}} & \multirow{2}{*}{\multicolumn{2}{|c|}{$\begin{array}{c}\text { Private } \\
\text { Institutions }\end{array}$}} & \multirow{3}{*}{$\begin{array}{c}\text { Full- } \\
\text { time } \\
\text { Faculty } \\
\text { Mean } \\
\end{array}$} & \multirow{3}{*}{$\begin{array}{c}\text { Part- } \\
\text { time } \\
\text { Faculty } \\
\text { Mean } \\
\end{array}$} & \multirow{3}{*}{$\begin{array}{c}\text { Graduates } \\
\text { per year } \\
\text { Mean } \\
\end{array}$} & \multicolumn{5}{|c|}{ Association Membership } \\
\hline & & & & & & & & & & & $\mathrm{NCA}$ & ECA & CSCA & SSCA & WSCA \\
\hline & & $n$ & $\%$ & $n$ & $\%$ & $n$ & $\%$ & & & & $n$ & $n$ & $n$ & $n$ & $n$ \\
\hline \multirow{3}{*}{$\begin{array}{l}\text { Doctoral } \\
\text { Level } \\
\text { Institutions }\end{array}$} & Extensive & 9 & 9.1 & 9 & 9.1 & 0 & - & 18.7 & 7.6 & 118.1 & 8 & 0 & 2 & 1 & 1 \\
\hline & Intensive & 8 & 8.1 & 4 & 4 & 4 & 4 & 13.1 & 17.2 & 65.2 & 7 & 0 & 1 & 1 & 1 \\
\hline & Total & 17 & 17.3 & 13 & 13.2 & 4 & 4 & 16 & 12.1 & 91.6 & 15 & 0 & 3 & 2 & 2 \\
\hline \multirow{3}{*}{$\begin{array}{l}\text { Masters } \\
\text { Level } \\
\text { Institutions }\end{array}$} & Level I & 35 & 35.7 & 20 & 20.4 & 15 & 15.3 & 10.1 & 10.4 & 57.6 & 21 & 0 & 1 & 4 & 4 \\
\hline & Level II & 7 & 7.1 & 1 & 1 & 6 & 6.1 & 5.2 & 4 & 34.5 & 3 & 0 & 1 & 0 & 1 \\
\hline & Total & 42 & 42.8 & 21 & 21.4 & 21 & 21.4 & 9.2 & 9.3 & 53.5 & 24 & 0 & 2 & 4 & 5 \\
\hline \multirow{3}{*}{$\begin{array}{l}\text { Baccalaureate } \\
\text { Colleges }\end{array}$} & $\begin{array}{l}\text { Liberal } \\
\text { Arts }\end{array}$ & 8 & 8.1 & 2 & 2 & 6 & 6.1 & 8.1 & 5.7 & 43.5 & 6 & 2 & 2 & 1 & 1 \\
\hline & General & 12 & 12.2 & 2 & 2 & 10 & 10.2 & 4.5 & 3.6 & 19.9 & 4 & 1 & 3 & 0 & 0 \\
\hline & Total & 20 & 20.4 & 4 & 4 & 16 & 16.3 & 5.9 & 4.37 & 29 & 10 & 3 & 5 & 1 & 1 \\
\hline Associates & Total & 18 & 18.3 & 18 & 18.3 & 0 & - & 4.4 & 7.8 & 112.1 & 6 & 1 & 1 & 1 & 2 \\
\hline Total & & 98 & 100 & 56 & 57.1 & 41 & 41.8 & 8.9 & 8.5 & 60.7 & 55 & 4 & 10 & 7 & 10 \\
\hline
\end{tabular}


Survey respondents were asked to indicate their view of the level of development of their departmental assessment plan (see Table 3). Over half of respondents $(61.1 \%)$ indicated that an assessment plan was currently in place in their department. The majority of respondents $(61.1 \%)$ also stated that assessment was a routine activity used for curriculum changes and accreditation purposes within their department (see Table 4).

\section{Table 3}

Departmental Assessment Level

\begin{tabular}{lcc}
\hline Assessment Progress to Date & $n$ & $\%$ \\
\hline Department has not created an assessment plan & 6 & $6.3 \%$ \\
Department is in the beginning stages of an assessment plan & 12 & $12.6 \%$ \\
Has developed an assessment plan but it is not yet implemented & 19 & $20 \%$ \\
Has implemented an assessment plan & 58 & $61.1 \%$ \\
Missing & 3 & $3.1 \%$ \\
\hline
\end{tabular}

Table 4

The Assessment Process

Frequency of Assessment

$\%$

Episodic; during program review for accreditation only 14 $14.7 \%$

Episodic; occurs as needed for curriculum changes 6

On-going: routine activity for accreditation only 5

On-going: routine activity for curriculum change and accreditation 58

$61.1 \%$

On-going: routine activity for curriculum change only 12 $12.6 \%$

Missing Additionally, survey respondents were asked to describe the frequency of assessment practices within their department (see Table 5). Fifty-one percent of chairs indicated that they 
collected assessment data very often, however, only $22 \%$ of chairs reported analyzing that assessment data very often. Department chairs also indicated that their assessment processes focused on student learning (43.2\%) and accountability (39.6\%) often.

Table 5

Frequency of Departmental Assessment Practices

\begin{tabular}{|c|c|c|c|c|c|c|c|c|}
\hline \multirow[t]{2}{*}{ Extent of practice } & \multicolumn{2}{|c|}{$\begin{array}{l}\text { Assessment data } \\
\text { are collected }\end{array}$} & \multicolumn{2}{|c|}{$\begin{array}{l}\text { Assessment data } \\
\text { are analyzed }\end{array}$} & \multicolumn{2}{|c|}{$\begin{array}{c}\text { Assessment } \\
\text { focuses on } \\
\text { student learning }\end{array}$} & \multicolumn{2}{|c|}{$\begin{array}{l}\text { Assessment } \\
\text { focuses on } \\
\text { accountability }\end{array}$} \\
\hline & $n$ & $\%$ & $n$ & $\%$ & $n$ & $\%$ & $n$ & $\%$ \\
\hline Very Often & 49 & 51 & 21 & 21.9 & 36 & 37.9 & 30 & 31.3 \\
\hline Often & 29 & 30.2 & 49 & 51 & 41 & 43.2 & 38 & 39.6 \\
\hline Sometimes & 3 & 3.1 & 10 & 10.4 & 13 & 13.7 & 18 & 18.8 \\
\hline Rarely & 5 & 5.2 & 5 & 5.2 & 3 & 3.2 & 9 & 9.4 \\
\hline Never & 10 & 10.4 & 11 & 11.5 & 2 & 2.1 & 1 & 1 \\
\hline Missing & 2 & 2 & 2 & 2 & 3 & 3.1 & 2 & 2.1 \\
\hline
\end{tabular}

Respondents were asked to indicate whether their student learning outcomes reflect departmental goals and objectives and their institution's mission and values (see Table 6). The majority $(94 \%)$ of respondents indicated that their student learning outcomes often or very often reflected their program goals. Fifty-four percent of respondents also indicated that their student learning outcomes very often reflected their institutional mission. 
Table 6

Student Learning Outcomes (SLOs) Reflection of Department and Institution

\begin{tabular}{lcccc}
\hline Extent & $\begin{array}{c}\text { SLOs reflect departmental goals and } \\
\text { objectives for learning } \\
n\end{array}$ & $\%$ & \multicolumn{2}{c}{$\begin{array}{c}\text { SLOs reflect institution's mission } \\
\text { and values }\end{array}$} \\
\hline Very Often & 57 & 59.4 & 52 & $\%$ \\
Often & 33 & 34.4 & 33 & 34.4 \\
Sometimes & 3 & 3.1 & 7 & 7.3 \\
Rarely & 1 & 1 & 3 & 3.1 \\
Never & 2 & 2.1 & 1 & 1 \\
Missing & 2 & 2.1 & 2 & 2.1 \\
\hline
\end{tabular}

\section{Limitations}

There are several limitations inherent with this type of study. First, due to current pressures on academic departments to fulfill college and institution assessment requirements (Cheng, 2001), there may be strong social desirability bias to exaggerate current assessment practices. In addition, department chairs in programs with limited or no assessment practices may be less inclined to complete a survey describing their assessment protocol resulting in a response bias. These issues could lead to systematic errors with a bias toward programs with comprehensive assessment plans. Moreover, there may be misconceptions of assessment vocabulary based on limited awareness of the field of assessment, leading to additional systematic errors.

Random errors also are a concern. In many cases, department chairs carry a great deal of responsibility (Hatfield, 1999) and may not be able to take the time to complete a questionnaire. 
Also, the NCA Directory (2003) may not be updated, leading to incorrect contact information and contributing to the poor response rate.

This chapter discussed the methodology utilized to conduct this study. A review of the study and the research questions were first addressed. Survey design and data collection methods were reviewed, including the pilot study. The population and sample were described in detail including respondent demographics. Finally, limitations of this quantitative study were reviewed. The next chapter discusses results specific to each research question utilized for this study. 


\section{CHAPTER 4: RESULTS}

The previous chapter discussed the population and methodology utilized to conduct this study as well as limitations that may influence the results. This chapter will discuss the research questions put forth for the study and the results of the investigation. Pertinent results for each question are discussed in text following each research question. Comprehensive results are displayed in tabular format for each of the study's research questions.

\section{Research Question One}

\section{1a. At the program level, what student learning objectives or outcomes are expected from undergraduates?}

Frequency analyses were computed on items 9 through 16 to determine levels of cognition, types of knowledge, and the extent to which affective and psychomotor domains of learning were evidenced by intended student learner outcomes. Respondents were asked to indicate the extent to which types of student learning outcomes were addressed in their respective programs (see Table 7).

When asked whether student learning outcomes focused on retrieving relevant knowledge from long-term memory, $36.6 \%$ of respondents indicated that this was addressed often or very often. However, $51.6 \%$ of department chairs reported that SLOs sometimes address the retrieval of relevant knowledge. Participants were asked whether student learning outcomes focus on understanding and constructing meaning from instructional messages. Eighty percent of respondents indicated that this was addressed often or very often in their department. When asked the extent to which student learning outcomes focus on applying and implementing procedures in a given situation, $74.4 \%$ of respondents indicated often or very often (see Table 7). 
Respondents were asked to indicate the extent to which their departmental student learning outcomes focus on analyzing and breaking material into parts to determine relationships and overall structure. Department chairs indicated that this item was often $(37.2 \%)$ or very often (25.5\%) addressed (see Table 7).

When asked whether student learning outcomes address evaluating and making judgments based on criteria and standards, $79.4 \%$ of respondents indicated often or very often. Respondents were asked to indicate whether their student learning outcomes addressed creating and putting elements together to form a coherent of functional whole and reorganizing elements into a new pattern or structure. More than $71 \%$ of respondents indicated often or very often (see Table 7).

Respondents also reflected on the extent to which their student learning outcomes focus on affective (attitudes, values and emotions) and psychomotor (skills, performance abilities) dimensions. With regard to affective dimensions, $43 \%$ of respondents indicated often, or very often. However, $65.2 \%$ of participants indicated that psychomotor or performance dimensions are addressed often or very often. 
Table 7

Type of Student Learning Outcomes (SLOs) Expected of Undergraduates

\begin{tabular}{|c|c|c|c|c|c|c|c|c|c|c|c|c|c|c|c|c|}
\hline \multirow[t]{2}{*}{$\begin{array}{l}\text { Extent of } \\
\text { type of } \\
\text { SLOs }\end{array}$} & \multicolumn{2}{|c|}{$\begin{array}{c}\text { Retrieve } \\
\text { relevant } \\
\text { knowledge }\end{array}$} & \multicolumn{2}{|c|}{$\begin{array}{l}\text { Understand/ } \\
\text { construct } \\
\text { meaning } \\
\text { from } \\
\text { messages }\end{array}$} & \multicolumn{2}{|c|}{$\begin{array}{l}\text { Apply and } \\
\text { implement } \\
\text { procedures } \\
\text { in a given } \\
\text { situation }\end{array}$} & \multicolumn{2}{|c|}{$\begin{array}{l}\text { Analyze/ } \\
\text { break } \\
\text { material into } \\
\text { parts to } \\
\text { determine } \\
\text { overall } \\
\text { structure }\end{array}$} & \multicolumn{2}{|c|}{$\begin{array}{l}\text { Evaluate } \\
\text { and make } \\
\text { judgments } \\
\text { based on } \\
\text { criteria and } \\
\text { standards }\end{array}$} & \multicolumn{2}{|c|}{$\begin{array}{l}\text { Create and } \\
\text { put elements } \\
\text { together to } \\
\text { form a } \\
\text { coherent } \\
\text { whole }\end{array}$} & \multicolumn{2}{|c|}{$\begin{array}{c}\text { Affective } \\
\text { dimensions }\end{array}$} & \multicolumn{2}{|c|}{$\begin{array}{c}\text { Psychomotor } \\
\text { dimensions }\end{array}$} \\
\hline & $n$ & $\%$ & $n$ & $\%$ & $n$ & $\%$ & $n$ & $\%$ & $n$ & $\%$ & $n$ & $\%$ & $n$ & $\%$ & $n$ & $\%$ \\
\hline Very Often & 10 & 10.8 & 45 & 47.4 & 28 & 29.8 & 24 & 25.5 & 33 & 35.9 & 27 & 29.7 & 15 & 16.1 & 27 & 29 \\
\hline Often & 24 & 25.8 & 31 & 32.6 & 42 & 44.7 & 35 & 37.2 & 40 & 43.5 & 37 & 40.7 & 25 & 26.8 & 35 & 37.6 \\
\hline Sometimes & 48 & 51.6 & 13 & 13.7 & 22 & 23.4 & 24 & 25.5 & 18 & 19.6 & 21 & 23.1 & 34 & 36.6 & 29 & 31.2 \\
\hline Rarely & 9 & 9.7 & 4 & 4.2 & 1 & 1.1 & 8 & 8.5 & 1 & 1.1 & 3 & 3.3 & 14 & 15.1 & 2 & 2.2 \\
\hline Never & 2 & 2.2 & 2 & 2.1 & 1 & 1.1 & 2 & 2.1 & 0 & - & 3 & 3.3 & 5 & 5.4 & 0 & - \\
\hline Missing & 5 & 5.1 & 3 & 3.1 & 4 & 4.1 & 4 & 4.1 & 6 & 6.1 & 7 & 7.1 & 5 & 5.1 & 5 & 5.1 \\
\hline
\end{tabular}


Characteristics of undergraduate communication program student learning outcomes also were measured through frequency analyses. Items addressed how student learning outcomes (SLOs) were created, how and to the extent to which SLOs were shared with faculty and students, and what aspects the SLOs addressed throughout the curriculum.

When asked if SLOs were developed in accordance with program mission statements 91.5\% of chairs indicated that their SLOs were developed often or very often in accordance with their program mission (see Table 8).

Participants were asked to indicate the extent to which they perceived their student learning outcomes were clear. Eighty-three percent indicated that their SLOs were often or very often clear. When asked whether student learning outcomes were shared with faculty, $87.2 \%$ of respondents indicated that they were often or very often shared with faculty. With regard to sharing SLOs with students, 55.3\% of respondents indicated often or very often. Over 10\% of respondents indicated that they rarely or never share SLOs with students. Four participants did not respond to this question. Fifty-three percent of chairs reported that pre-students were informed very often or often of student learning outcomes (see Table 8).

When asked whether students were informed of intended student learning outcomes throughout the program, almost $68.8 \%$ of participants indicated that students were often or very often informed. Respondents were asked whether students were aware of student learning outcomes upon graduation. Almost $61 \%$ of respondents indicated that students were often or very often aware of SLOs upon graduation (see Table 8). 
Table 8

Characteristics of Student Learning Outcomes (SLOs)

\begin{tabular}{|c|c|c|c|c|c|c|c|c|c|c|c|c|c|c|}
\hline \multirow[t]{2}{*}{$\begin{array}{l}\text { Extent of } \\
\text { SLO } \\
\text { Characteristic }\end{array}$} & \multicolumn{2}{|c|}{$\begin{array}{c}\text { SLOs develop } \\
\text { with program } \\
\text { mission }\end{array}$} & \multicolumn{2}{|c|}{ SLOs are clear } & \multicolumn{2}{|c|}{$\begin{array}{l}\text { SLOs shared } \\
\text { with faculty }\end{array}$} & \multicolumn{2}{|c|}{$\begin{array}{l}\text { SLOs shared } \\
\text { with students }\end{array}$} & \multicolumn{2}{|c|}{$\begin{array}{l}\text { SLOs shared } \\
\text { with pre- } \\
\text { students }\end{array}$} & \multicolumn{2}{|c|}{$\begin{array}{l}\text { SLOs shared } \\
\text { with students } \\
\text { through } \\
\text { program }\end{array}$} & \multicolumn{2}{|c|}{$\begin{array}{l}\text { Students aware } \\
\text { of SLOs at grad }\end{array}$} \\
\hline & $n$ & $\%$ & $n$ & $\%$ & $n$ & $\%$ & $n$ & $\%$ & $n$ & $\%$ & $n$ & $\%$ & $n$ & $\%$ \\
\hline Very Often & 60 & 63.8 & 39 & 41.5 & 64 & 68.1 & 35 & 37.2 & 28 & 30.1 & 24 & 25.8 & 28 & 30.4 \\
\hline Often & 26 & 27.7 & 39 & 41.5 & 18 & 19.1 & 17 & 18.1 & 21 & 22.6 & 40 & 43 & 28 & 30.4 \\
\hline Sometimes & 6 & 6.1 & 14 & 14.9 & 9 & 9.6 & 24 & 25.5 & 21 & 22.6 & 19 & 20.4 & 26 & 26.5 \\
\hline Rarely & 0 & - & 1 & 1.1 & 1 & 1.1 & 10 & 10.6 & 15 & 16.1 & 4 & 4.3 & 6 & 6.1 \\
\hline Never & 2 & 2.1 & 1 & 1.1 & 2 & 2.1 & 8 & 8.5 & 8 & 8.5 & 6 & 6.5 & 4 & 4.1 \\
\hline Missing & 4 & 4.1 & 4 & 4.1 & 4 & 4.1 & 4 & 4.1 & 5 & 5.1 & 5 & 5.1 & 6 & 6.1 \\
\hline
\end{tabular}


Over 60 percent of respondents indicated that their student learning outcomes were developed with faculty often or very often. When asked whether student learning outcomes were implemented into their curriculum, almost $70 \%$ of respondents indicated often or very often. Although four respondents declined to answer the question, no one else indicated that SLOs were never implemented into their curriculum, and $6.1 \%$ of participants indicated that student learning outcomes were rarely implemented (see Table 9).

Participants were asked whether or not their student learning outcomes focus on skills or abilities central to the discipline of Communication Studies. Results showed that $95.8 \%$ of respondents indicated SLOs were often or very often central to Communication Studies. When asked whether students were provided with multiple ways to demonstrate their learning of intended student learning outcomes, $62.7 \%$ indicated often or very often. Respondents were also asked whether multiple teaching methods were used to further student learning outcomes. Almost $80.6 \%$ of participants indicated often or very often (see Table 9)

Participants were asked to indicate whether course student learning outcomes reinforce program learning outcomes. All program chairs indicated that course SLOs reinforce program SLOs often or very often.

When asked whether their curriculum fosters student learning outcomes, $84.7 \%$ of participants indicated often or very often. Two respondents indicated that their curriculum rarely fosters their student learning outcomes (see Table 9). 
Table 9

Characteristics of Student Learning Outcomes (SLOs) (Frequency)

\begin{tabular}{|c|c|c|c|c|c|c|c|c|c|c|c|c|c|c|}
\hline \multirow[t]{2}{*}{$\begin{array}{l}\text { Extent of SLO } \\
\text { Characteristic }\end{array}$} & \multicolumn{2}{|c|}{$\begin{array}{l}\text { SLOs develop } \\
\text { with faculty }\end{array}$} & \multicolumn{2}{|c|}{$\begin{array}{l}\text { SLOs } \\
\text { implemented } \\
\text { into curriculum }\end{array}$} & \multicolumn{2}{|c|}{$\begin{array}{l}\text { SLOs focus on } \\
\text { abilities central } \\
\text { to discipline }\end{array}$} & \multicolumn{2}{|c|}{$\begin{array}{c}\text { Students } \\
\text { provided } \\
\text { multiple ways } \\
\text { of } \\
\text { demonstrating } \\
\text { SLOs } \\
\end{array}$} & \multicolumn{2}{|c|}{$\begin{array}{c}\text { Multiple } \\
\text { teaching } \\
\text { methods used } \\
\text { to further SLOs }\end{array}$} & \multicolumn{2}{|c|}{$\begin{array}{l}\text { Course SLOs } \\
\text { reinforce } \\
\text { program SLOs }\end{array}$} & \multicolumn{2}{|c|}{$\begin{array}{l}\text { Curriculum } \\
\text { fosters SLOs }\end{array}$} \\
\hline & $n$ & $\%$ & $n$ & $\%$ & $n$ & $\%$ & $n$ & $\%$ & $n$ & $\%$ & $n$ & $\%$ & $n$ & $\%$ \\
\hline Very Often & 36 & 36.7 & 30 & 31.9 & 50 & 53.2 & 32 & 34 & 44 & 47.3 & 47 & 51.1 & 43 & 46.7 \\
\hline Often & 24 & 24.5 & 34 & 36.2 & 40 & 42.6 & 27 & 28.7 & 31 & 33.3 & 32 & 34.8 & 35 & 38 \\
\hline Sometimes & 15 & 15.3 & 24 & 25.5 & 3 & 3.2 & 31 & 33 & 16 & 17.2 & 13 & 14.1 & 12 & 13 \\
\hline Rarely & 11 & 11.2 & 6 & 6.4 & 1 & 1.1 & 2 & 2.1 & 2 & 2.2 & 0 & - & 2 & 2.2 \\
\hline Never & 7 & 7.1 & 0 & - & 0 & - & 2 & 2.1 & 0 & - & 0 & - & 0 & - \\
\hline Missing & 5 & 5.1 & 4 & 4.1 & 4 & 4.1 & 4 & 4.1 & 5 & 5.1 & 6 & 6.1 & 6 & 6.1 \\
\hline
\end{tabular}




\section{1b. To what extent are student learning outcomes being measured? How are they measured?}

Frequency analyses were computed on items 32 through 41 to determine the extent to which direct assessment methods are being used in undergraduate communication studies departments. During students' senior year as undergraduates, $37.8 \%$ of program chairs indicated that they used student portfolios for assessment purposes (see Table 10). Course embedded assignments were utilized by departments for assessment purposes $32.7 \%$ during all four years of students' college careers. The direct assessment utilized most often by program chairs was capstone projects (67.3\%). Similarly, 59.2\% of program chairs revealed that internships are used to assess student learning during students' senior year and $43.9 \%$ during the junior year. Course embedded assignments, faculty designed tests, and essays are most frequently used during all years of schooling for assessment purposes according to survey respondents.

Items 42 through 48 were examined through frequency analyses to determine the extent to which indirect assessment methods are utilized. As displayed in Table 11, alumni surveys are used at $31.6 \%$ of departments every 5 to 6 years for assessment purposes. Student surveys are used at $25.5 \%$ of departments every year to assess student learning. Over half of the departments surveyed indicated that they never utilize employer surveys, focus groups, exit interviews or reflection papers. 
Table 10

Frequency of Types of Direct Assessment Methods Used

\begin{tabular}{|c|c|c|c|c|c|c|c|c|c|c|c|c|c|c|c|c|c|c|}
\hline \multirow[t]{2}{*}{$\begin{array}{l}\text { Point } \\
\text { assessed }\end{array}$} & \multicolumn{2}{|c|}{$\begin{array}{l}\text { Student } \\
\text { portfolios }\end{array}$} & \multicolumn{2}{|c|}{$\begin{array}{c}\text { Course } \\
\text { embedded } \\
\text { Assign }\end{array}$} & \multicolumn{2}{|c|}{$\begin{array}{l}\text { Capstone } \\
\text { projects }\end{array}$} & \multicolumn{2}{|c|}{$\begin{array}{c}\text { Juried } \\
\text { reviews of } \\
\text { student } \\
\text { projects }\end{array}$} & \multicolumn{2}{|c|}{$\begin{array}{c}\text { Case } \\
\text { studies }\end{array}$} & \multicolumn{2}{|c|}{ Internship } & \multicolumn{2}{|c|}{ Essays } & \multicolumn{2}{|c|}{$\begin{array}{l}\text { Faculty } \\
\text { designed } \\
\text { tests }\end{array}$} & \multicolumn{2}{|c|}{$\begin{array}{l}\text { Standar } \\
\text { d tests }\end{array}$} \\
\hline & $n$ & $\%$ & $n$ & $\%$ & $n$ & $\%$ & $n$ & $\%$ & $n$ & $\%$ & $n$ & $\%$ & $n$ & $\%$ & $n$ & $\%$ & $n$ & $\%$ \\
\hline $\begin{array}{l}\text { Freshmen } \\
\text { Year }\end{array}$ & 4 & 4.1 & 26 & 26.5 & 3 & 3.1 & 3 & 3.1 & 6 & 6.1 & 1 & 1 & 23 & 23.5 & 25 & 25.5 & 11 & $\begin{array}{l}1 \\
1\end{array}$ \\
\hline $\begin{array}{l}\text { Sophomor } \\
\text { e Year }\end{array}$ & 12 & 12.2 & 34 & 34.7 & 10 & 10.2 & 4 & 4.1 & 12 & 12.2 & 4 & 4.1 & 30 & 30.6 & 29 & 29.6 & 9 & $\begin{array}{l}9 \\
\dot{2}\end{array}$ \\
\hline $\begin{array}{l}\text { Junior } \\
\text { Year }\end{array}$ & 9 & 9.2 & 19 & 19.4 & 9 & 9.2 & 2 & 2 & 23 & 23.5 & 43 & 43.9 & 22 & 22.4 & 18 & 18.4 & 6 & $\begin{array}{l}6 \\
1\end{array}$ \\
\hline $\begin{array}{l}\text { Senior } \\
\text { Year }\end{array}$ & 37 & 37.8 & 33 & 33.7 & 66 & 67.3 & 22 & 22.4 & 24 & 24.5 & 58 & 59.2 & 33 & 33.7 & 24 & 24.5 & 9 & $\begin{array}{l}9 \\
\dot{2}\end{array}$ \\
\hline All & 2 & 2.0 & 32 & 32.7 & 2 & 2 & 3 & 3.1 & 8 & 8.2 & 5 & 5.1 & 25 & 25.5 & 32 & 32.7 & 7 & $\begin{array}{l}7 \\
1\end{array}$ \\
\hline N/A & 42 & 42.9 & 12 & 12.2 & 16 & 16.3 & 63 & 63.3 & 45 & 45.9 & 26 & 26.5 & 20 & 20.4 & 21 & 21.4 & 65 & 6 \\
\hline
\end{tabular}


Table 11

Frequency of Types of Indirect Assessment Methods Used

\begin{tabular}{|c|c|c|c|c|c|c|c|c|c|c|c|c|}
\hline \multirow[t]{2}{*}{$\begin{array}{l}\text { Extent of } \\
\text { method used }\end{array}$} & \multicolumn{2}{|c|}{ Alumni surveys } & \multicolumn{2}{|c|}{ Student surveys } & \multicolumn{2}{|c|}{$\begin{array}{l}\text { Employer } \\
\text { surveys }\end{array}$} & \multicolumn{2}{|c|}{ Focus groups } & \multicolumn{2}{|c|}{ Exit interviews } & \multicolumn{2}{|c|}{$\begin{array}{l}\text { Reflection } \\
\text { papers }\end{array}$} \\
\hline & $n$ & $\%$ & $n$ & $\%$ & $n$ & $\%$ & $n$ & $\%$ & $n$ & $\%$ & $n$ & $\%$ \\
\hline $\begin{array}{l}\text { Every } \\
\text { Semester }\end{array}$ & 0 & - & 17 & 17.3 & 6 & 6.1 & 0 & - & 13 & 13.3 & 21 & 21.4 \\
\hline Once a Year & 10 & 10.2 & 25 & 25.5 & 5 & 5.1 & 6 & 6.1 & 19 & 19.4 & 10 & 10.2 \\
\hline $\begin{array}{l}\text { Every } 2 \text { to } 3 \\
\text { Years }\end{array}$ & 17 & 17.3 & 9 & 9.2 & 9 & 9.2 & 10 & 10.2 & 2 & 2 & 4 & 4.1 \\
\hline $\begin{array}{l}\text { Every } 3 \text { to } 4 \\
\text { Years }\end{array}$ & 14 & 14.3 & 10 & 10.2 & 1 & 1 & 5 & 5.1 & 3 & 3.1 & 3 & 3.1 \\
\hline $\begin{array}{l}\text { Every } 5 \text { to } 6 \\
\text { Years }\end{array}$ & 31 & 31.6 & 10 & 10.2 & 9 & 9.2 & 7 & 7.1 & 1 & 1 & 0 & - \\
\hline Never & 19 & 19.4 & 21 & 21.4 & 59 & 60.2 & 64 & 65.3 & 53 & 54.1 & 52 & 53.1 \\
\hline Missing & 7 & 7.1 & 6 & 6.1 & 9 & 9.2 & 6 & 8.2 & 7 & 7.1 & 8 & 8.2 \\
\hline
\end{tabular}




\section{1c. To what extent are assessment results utilized to make program improvements? How are they used to make improvements?}

Frequency analyses were computed on items 49 through 55 to determine the extent to which direct and indirect assessment results were utilized to make improvements to communication studies programs. As shown in Table 12,70.4\% respondents indicated that they utilize assessment results very often or often to make curricular changes within the department. Results of this study revealed that $32.6 \%$ of communication studies department chairs indicated that they utilize assessment results to determine resource allocations often or very often. Similarly, $67.4 \%$ of respondents indicated that they use results for program planning and decision making often or very often. Assessment results are used for program review often or very often by $84.7 \%$ of department chairs according to respondents. Fifty-three percent of respondents indicated that assessment results are rarely or never used for student recruitment. However, these results are used for improving student learning (75.5\%) and evaluation of the assessment process $(61.2 \%)$. 
Table 12

Frequency of Use of Assessment Results to Make Program Improvements

\begin{tabular}{|c|c|c|c|c|c|c|c|c|c|c|c|c|c|c|}
\hline \multirow[t]{2}{*}{$\begin{array}{l}\text { Extent of } \\
\text { method used }\end{array}$} & \multicolumn{2}{|c|}{$\begin{array}{l}\text { Curricular } \\
\text { changes }\end{array}$} & \multicolumn{2}{|c|}{$\begin{array}{l}\text { Resource } \\
\text { allocation }\end{array}$} & \multicolumn{2}{|c|}{$\begin{array}{l}\text { Program } \\
\text { planning and } \\
\text { decision } \\
\text { making }\end{array}$} & \multicolumn{2}{|c|}{$\begin{array}{l}\text { Program } \\
\text { review }\end{array}$} & \multicolumn{2}{|c|}{$\begin{array}{l}\text { Recruit } \\
\text { students }\end{array}$} & \multicolumn{2}{|c|}{$\begin{array}{l}\text { Improving } \\
\text { student } \\
\text { learning }\end{array}$} & \multicolumn{2}{|c|}{$\begin{array}{l}\text { Evaluation of } \\
\text { the assessment } \\
\text { process }\end{array}$} \\
\hline & $n$ & $\%$ & $n$ & $\%$ & $n$ & $\%$ & $n$ & $\%$ & $n$ & $\%$ & $n$ & $\%$ & $n$ & $\%$ \\
\hline Very Often & 34 & 34.7 & 11 & 11.2 & 33 & 33.7 & 45 & 45.9 & 7 & 7.1 & 36 & 36.7 & 29 & 29.6 \\
\hline Often & 35 & 35.7 & 21 & 21.4 & 33 & 33.7 & 38 & 38.8 & 13 & 13.3 & 38 & 38.8 & 31 & 31.6 \\
\hline Sometimes & 23 & 23.5 & 28 & 28.6 & 24 & 24.5 & 9 & 9.2 & 26 & 26.5 & 15 & 15.3 & 24 & 24.5 \\
\hline Rarely & 2 & 2 & 21 & 21.4 & 2 & 2 & 2 & 2 & 26 & 26.5 & 2 & 2 & 7 & 7.1 \\
\hline Never & 0 & - & 12 & 12.2 & 2 & 2 & 0 & - & 20 & 20.4 & 1 & 1 & 3 & 3.1 \\
\hline Missing & 4 & 4.1 & 5 & 5.1 & 4 & 4.1 & 4 & 4.1 & 6 & 6.1 & 6 & 6.1 & 4 & 4.1 \\
\hline
\end{tabular}




\section{Research Question Two}

\section{To what degree are assessment results communicated and to what audiences? How are results communicated?}

Frequency analyses were computed on items 57 through 64 to determine the various audiences to whom assessment results are communicated. As Table 13 indicates, the majority of respondents rarely or never share assessment results with students, the general public, and alumni organizations. Respondents more frequently share results with faculty and administrators.

Frequencies from items 66 through 72 were analyzed to determine how results are disseminated to various audiences. Table 14 indicates that respondents rarely or never share assessment results through student newspapers. The most frequent method of assessment result dissemination is through accrediting organization reports or governance board reports. However, marketing campaigns, institutional websites, institutional catalogs and brochures and conference presentations and workshops are rarely or never used to disseminate results of assessment efforts according to department chairs. 
Table 13

Audience Types to which Assessment Results are Communicated

\begin{tabular}{|c|c|c|c|c|c|c|c|c|c|c|c|c|c|c|c|c|}
\hline $\begin{array}{l}\text { Extent of } \\
\text { communication } \\
\text { to audience type }\end{array}$ & \multicolumn{2}{|c|}{ Students } & \multicolumn{2}{|c|}{ Faculty } & \multicolumn{2}{|c|}{ Admin } & \multicolumn{2}{|c|}{$\begin{array}{l}\text { Governing } \\
\text { board }\end{array}$} & \multicolumn{2}{|c|}{ Parents } & \multicolumn{2}{|c|}{$\begin{array}{l}\text { Accrediting } \\
\text { organization }\end{array}$} & \multicolumn{2}{|c|}{$\begin{array}{l}\text { General } \\
\text { public }\end{array}$} & \multicolumn{2}{|c|}{$\begin{array}{c}\text { Alumni } \\
\text { organization }\end{array}$} \\
\hline Very Often & 2 & 2 & 55 & 56.1 & 58 & 59.2 & 13 & 13.3 & 0 & - & 34 & 34.7 & 0 & - & 1 & 1 \\
\hline Often & 7 & 7.1 & 25 & 25.5 & 27 & 27.6 & 13 & 13.3 & 1 & 1 & 17 & 17.3 & 1 & 1 & 1 & 1 \\
\hline Sometimes & 14 & 14.3 & 7 & 7.1 & 7 & 7.1 & 21 & 21.4 & 8 & 8.2 & 18 & 18.4 & 6 & 6.1 & 15 & 15.3 \\
\hline Never & 46 & 46.9 & 2 & 2 & 2 & 2.1 & 37 & 37.8 & 66 & 67.3 & 20 & 20.4 & 64 & 65.3 & 57 & 58.2 \\
\hline Missing & 6 & 6.1 & 6 & 6.1 & 4 & 4.1 & 9 & 9.2 & 7 & 7.1 & 6 & 6.1 & 7 & 7.1 & 9 & 9.2 \\
\hline
\end{tabular}


Table 14

Methods by which Assessment Results are Communicated

\begin{tabular}{|c|c|c|c|c|c|c|c|c|c|c|c|c|c|c|}
\hline \multirow[t]{2}{*}{$\begin{array}{l}\text { Extent of } \\
\text { method } \\
\text { used }\end{array}$} & \multicolumn{2}{|c|}{$\begin{array}{c}\text { School } \\
\text { newspaper }\end{array}$} & \multicolumn{2}{|c|}{$\begin{array}{l}\text { Accrediting } \\
\text { organization } \\
\text { reports }\end{array}$} & \multicolumn{2}{|c|}{$\begin{array}{l}\text { Governance } \\
\text { board reports }\end{array}$} & \multicolumn{2}{|c|}{$\begin{array}{l}\text { Marketing } \\
\text { campaigns }\end{array}$} & \multicolumn{2}{|c|}{$\begin{array}{l}\text { Institution } \\
\text { website }\end{array}$} & \multicolumn{2}{|c|}{$\begin{array}{c}\text { Institution } \\
\text { catalog and } \\
\text { brochure }\end{array}$} & \multicolumn{2}{|c|}{$\begin{array}{c}\text { Conference } \\
\text { presentations } \\
\text { and } \\
\text { workshops }\end{array}$} \\
\hline & $n$ & $\%$ & $n$ & $\%$ & $n$ & $\%$ & $n$ & $\%$ & $n$ & $\%$ & $n$ & $\%$ & $n$ & $\%$ \\
\hline Very Often & 0 & - & 34 & 34.7 & 12 & 12.2 & 1 & 1 & 1 & 1 & 4 & 4.1 & 6 & 6.1 \\
\hline Often & 2 & 2 & 19 & 19.4 & 23 & 23.5 & 7 & 7.1 & 10 & 10.2 & 11 & 11.2 & 11 & 11.2 \\
\hline Sometimes & 4 & 4.1 & 14 & 14.3 & 15 & 15.3 & 22 & 22.4 & 20 & 20.4 & 20 & 20.4 & 30 & 30.6 \\
\hline Rarely & 13 & 13.3 & 4 & 4.1 & 6 & 6.1 & 8 & 8.1 & 13 & 13.3 & 10 & 10.2 & 9 & 9.2 \\
\hline Never & 71 & 72.4 & 21 & 24.4 & 36 & 36.7 & 52 & 53.1 & 46 & 46.9 & 45 & 45.9 & 32 & 32.7 \\
\hline Missing & 8 & 8.2 & 6 & 6.1 & 6 & 6.1 & 8 & 8.2 & 8 & 8.2 & 8 & 8.2 & 10 & 10.2 \\
\hline
\end{tabular}




\section{Research Question Three}

\section{What institutional resources are provided for undergraduate communication program faculty to develop and implement assessment? How are faculty rewarded for assessment efforts?}

Frequency analyses were computed on items 74 through 77 to determine the extent to which the chair perceived the administration supports departmental assessment efforts. Table 15 indicates that $80.6 \%$ of respondents perceived verbal support from administrators for assessment efforts very often or often. However, respondents indicated that their administrations rarely or never allocated resources for assessment start up costs or to implement and maintain assessment efforts. These results are surprising, given that $62.7 \%$ of program chairs reported their programs had at least sometimes projected expenditures for assessment.

Items 87 through 94 were examined through frequency analyses to determine the extent to which faculty have received incentives for assessment efforts. As indicated in Table 16, the most frequent faculty incentives used for assessment efforts included time, small grants, travel to assessment conferences, and travel to other institutions. Most departments responded that very few of the incentives included in the survey were typically awarded for faculty assessment efforts (see Table 16).

Items 96 through 105 were examined through frequency analyses to determine the extent that faculty, according to the department chair, may benefit from their assessment efforts. As indicated in Tables 17 and 18, faculty benefits most often cited include increased interaction with faculty, inclusion of participation in the promotion and tenure process, increased understanding of institutional linkages, and personal expressions of gratitude from institutional leaders. According to the department chairs' responses, interaction with faculty at other institutions, 
letters of commendation, and journal publications of assessment results and presentations at national conferences are not seen as faculty benefits for assessment efforts. Tables 17 and 18 also indicate that respondents were divided in their view of some of the potential benefits for faculty assessment efforts. Two categories where respondents were especially divided about the benefits for faculty assessment efforts included the consideration of those efforts in promotion and tenure and the results of those efforts not being used against faculty. 
Table 15

Perceptions of Administrative Level Support for Program Assessment Efforts

\begin{tabular}{|c|c|c|c|c|c|c|c|c|}
\hline \multirow[t]{2}{*}{$\begin{array}{l}\text { Extent of } \\
\text { support }\end{array}$} & \multicolumn{2}{|c|}{$\begin{array}{l}\text { Program receives support } \\
\text { for assessment efforts }\end{array}$} & \multicolumn{2}{|c|}{$\begin{array}{l}\text { Program has articulated } \\
\text { projected expenditures for } \\
\text { assessment to } \\
\text { administrators }\end{array}$} & \multicolumn{2}{|c|}{$\begin{array}{l}\text { Administration has } \\
\text { allocated resources for } \\
\text { initial assessment costs }\end{array}$} & \multicolumn{2}{|c|}{$\begin{array}{l}\text { Administration has } \\
\text { allocated resources to } \\
\text { implement and maintain } \\
\text { assessment efforts }\end{array}$} \\
\hline & $n$ & $\%$ & $n$ & $\%$ & $n$ & $\%$ & $n$ & $\%$ \\
\hline Very Often & 55 & 56.1 & 22 & 22.4 & 19 & 19.4 & 20 & 20.4 \\
\hline Often & 24 & 24.5 & 22 & 22.4 & 11 & 11.2 & 17 & 17.3 \\
\hline Sometimes & 11 & 11.2 & 14 & 14.3 & 21 & 21.4 & 13 & 13.3 \\
\hline Rarely & 3 & 3.1 & 13 & 13.3 & 18 & 18.4 & 20 & 20.4 \\
\hline Never & 1 & 1 & 22 & 22.4 & 25 & 25.5 & 24 & 24.5 \\
\hline Missing & 4 & 4.1 & 5 & 5.1 & 4 & 4.1 & 4 & 4.1 \\
\hline
\end{tabular}


Table 16

Types of Faculty Incentives for Assessment Efforts

\begin{tabular}{|c|c|c|c|c|c|c|c|c|c|c|c|c|c|c|}
\hline \multirow[t]{2}{*}{$\begin{array}{l}\text { Extent of } \\
\text { method } \\
\text { used }\end{array}$} & \multicolumn{2}{|c|}{ Time } & \multicolumn{2}{|c|}{ Small grants } & \multicolumn{2}{|c|}{$\begin{array}{l}\text { Large grants } \\
\qquad(\$ 2,000+)\end{array}$} & \multicolumn{2}{|c|}{$\begin{array}{l}\text { Graduate } \\
\text { assistant }\end{array}$} & \multicolumn{2}{|c|}{$\begin{array}{l}\text { Travel to other } \\
\text { institutions }\end{array}$} & \multicolumn{2}{|c|}{ Stipends } & \multicolumn{2}{|c|}{$\begin{array}{c}\text { Travel to } \\
\text { assessment } \\
\text { conferences }\end{array}$} \\
\hline & $n$ & $\%$ & $n$ & $\%$ & $n$ & $\%$ & $n$ & $\%$ & $n$ & $\%$ & $n$ & $\%$ & $n$ & $\%$ \\
\hline $\begin{array}{l}\text { Every } \\
\text { semester }\end{array}$ & 8 & 8.2 & 5 & 5.8 & 0 & - & 1 & 1.2 & 4 & 4.8 & 2 & 2.4 & 7 & 8.1 \\
\hline $\begin{array}{l}\text { Once a } \\
\text { year }\end{array}$ & 10 & 10.2 & 10 & 11.6 & 4 & 4.9 & 0 & - & 11 & 13.1 & 4 & 4.8 & 12 & 14 \\
\hline $\begin{array}{l}\text { Every } 2 \\
\text { to } 3 \text { years }\end{array}$ & 0 & - & 3 & 3.5 & 0 & - & 1 & 1.2 & 9 & 10.7 & 2 & 2.4 & 9 & 10.5 \\
\hline $\begin{array}{l}\text { Every } 3 \\
\text { to } 4 \text { years }\end{array}$ & 2 & 2 & 3 & 3.5 & 1 & 1.2 & 0 & - & 2 & 2.4 & 3 & 3.6 & 6 & 7.0 \\
\hline $\begin{array}{l}\text { Every 5-6 } \\
\text { years }\end{array}$ & 2 & 2 & 4 & 4.7 & 1 & 1.2 & 0 & - & 1 & 1.2 & 1 & 1.2 & 3 & 3.5 \\
\hline Never & 62 & 63.3 & 61 & 70.9 & 76 & 92.7 & 82 & 97.6 & 57 & 67.9 & 72 & 85.7 & 48 & 55.8 \\
\hline Missing & 14 & 14.3 & 12 & 12.2 & 16 & 16.3 & 15 & 15.3 & 14 & 14.3 & 14 & 14.3 & 13 & 13.2 \\
\hline
\end{tabular}


Table 17

Faculty Benefits for Assessment

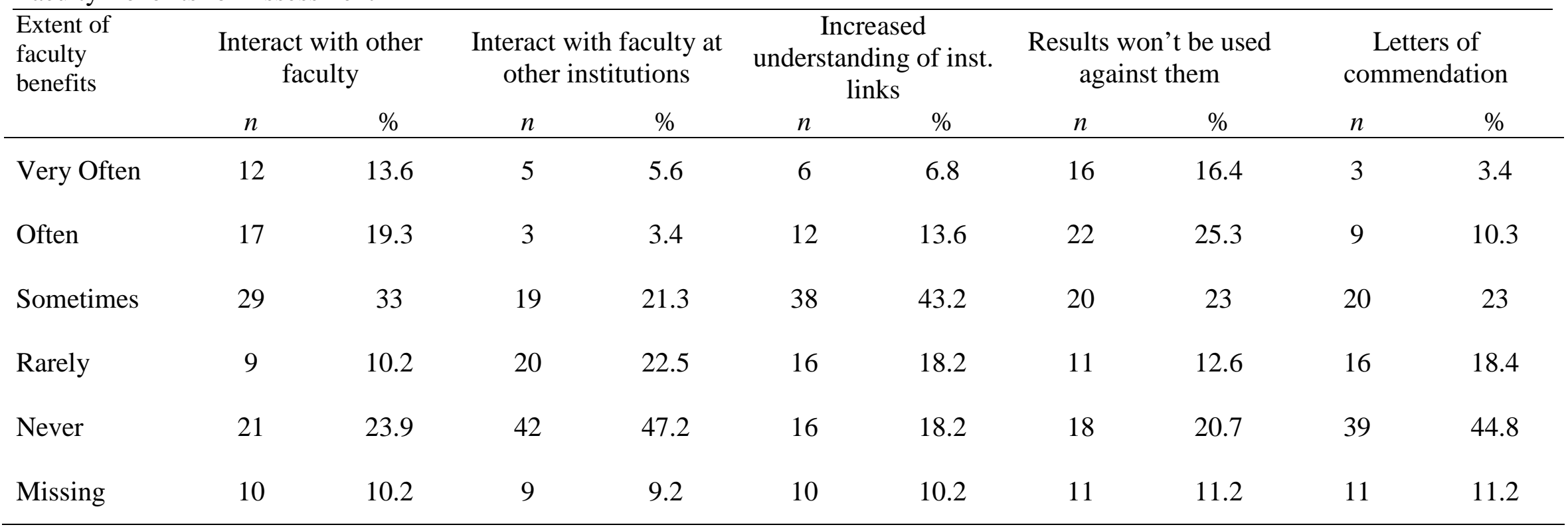


Table 18

Faculty Benefits for Assessment

\begin{tabular}{|c|c|c|c|c|c|c|c|c|c|c|}
\hline \multirow[t]{2}{*}{$\begin{array}{l}\text { Extent of } \\
\text { faculty } \\
\text { benefits }\end{array}$} & \multicolumn{2}{|c|}{$\begin{array}{l}\text { Public expressions of } \\
\text { gratitude from } \\
\text { institution leaders }\end{array}$} & \multicolumn{2}{|c|}{$\begin{array}{l}\text { Publish assessment } \\
\text { results in journals and } \\
\text { books }\end{array}$} & \multicolumn{2}{|c|}{$\begin{array}{l}\text { Present at national } \\
\text { conference }\end{array}$} & \multicolumn{2}{|c|}{$\begin{array}{c}\text { Inclusion in } \mathrm{P} \& \mathrm{~T} \\
\text { process }\end{array}$} & \multicolumn{2}{|c|}{$\begin{array}{l}\text { Personal expressions o } \\
\text { gratitude from } \\
\text { institution leaders }\end{array}$} \\
\hline & $n$ & $\%$ & $n$ & $\%$ & $n$ & $\%$ & $n$ & $\%$ & $n$ & $\%$ \\
\hline $\begin{array}{l}\text { Very } \\
\text { Often }\end{array}$ & 8 & 8.9 & 0 & - & 2 & 2.3 & 12 & 13.5 & 10 & 11.4 \\
\hline Often & 16 & 17.8 & 2 & 2.3 & 5 & 5.7 & 19 & 21.3 & 19 & 21.6 \\
\hline Sometimes & 17 & 18.9 & 8 & 9.2 & 19 & 21.8 & 18 & 20.2 & 21 & 23.9 \\
\hline Rarely & 18 & 20 & 17 & 19.5 & 15 & 17.2 & 11 & 12.4 & 19 & 21.6 \\
\hline Never & 31 & 34.4 & 60 & 69 & 46 & 52.9 & 29 & 32.6 & 19 & 21.6 \\
\hline Missing & 8 & 8.2 & 11 & 11.2 & 11 & 11.2 & 9 & 9.2 & 10 & 10.2 \\
\hline
\end{tabular}


Research Question Four

4. Is there a statistically significant difference in the extent to which communication studies undergraduate programs are implementing their assessment plans that vary according to different institution types (Carnegie Foundation for the Advancement of Teaching, 2000)?

a. Doctoral/Research Universities-Extensive and Intensive

b. Master's Colleges and Universities I and II

c. Baccalaureate Colleges-Liberal Arts and General

d. Associates Colleges

A Multivariate Analysis of Variance (MANOVA) was computed to determine if there were significant differences in how undergraduate communication studies programs were implementing their assessment plans based on their Carnegie Classification. For this analysis, institution type served as the independent variable, while the sum of questions 9 through 14 (Cognitive Student Learning Outcomes), 17 through 30 (Characteristics of Student Learning Outcomes) 32 through 41 (Direct Methods of Assessment), 42 through 47 (Indirect Methods of Assessment) and 49 through 55 (Utilization of Assessment Results) represented the five dependent variables. As discussed earlier, items within each category required the respondent to chose the most appropriate response ranging from very often (1) to never (5). Therefore, for the purpose of this study, lower numbers within the sum of each category represent a higher frequency of the item.

The results of the MANOVA revealed a significant model $(F(30,226)=1.60, p=.03$, Wilks' $\Lambda=.46$ ). A closer examination of the individual ANOVAs indicated that Characteristics of Student Learning Outcomes $(F(6,60)=3.02, p=.01)$ and Utilization of Assessment Results $(F(6,60)=3.86, p=.003)$ were significantly different based on Carnegie Classification (see 
Table 19). Specifically, results of a Tukey Multiple Comparison test showed that Associate Colleges more often adhered to principles of good practice in defining and utilizing their learning outcomes than did Liberal Arts or Masters I institutions (see Table 19). For example, according to the American Association of Higher Education (1992), one principle of good practice ensures that students are aware of intended learning outcomes as they are progressing through their academic program.

Results of a Tukey test also revealed a significant difference in the extent to which BA General $(M=11.8)$ and Masters II $(M=12.8)$ institutions utilize assessment results to make program improvements compared to Doctoral Extensive institutions $(M=21)$. As previously discussed, lower numbers on these items indicate more assessment activity. Therefore, BA General and Masters II institutions more thoroughly utilized assessment results to develop their undergraduate programs than did Doctoral Extensive institutions (see Table 19). 
Table 19

Analysis of Variance for Extent of Assessment by Institution Type

\begin{tabular}{|c|c|c|c|c|c|c|c|c|c|}
\hline & $\begin{array}{c}\text { Doctoral } \\
\text { Extensive }\end{array}$ & $\begin{array}{l}\text { Doctoral } \\
\text { Intensive }\end{array}$ & Masters I & Masters II & $\begin{array}{c}\text { BA } \\
\text { Liberal Arts }\end{array}$ & BA General & Associates & \multirow[b]{2}{*}{$F$} & \multirow{2}{*}{$e t a^{2}$} \\
\hline & $\begin{array}{c}\text { Mean }(n) \\
(\text { Item } \\
\text { Mean) }\end{array}$ & $\begin{array}{c}\text { Mean }(n) \\
(\text { Item } \\
\text { Mean) }\end{array}$ & $\begin{array}{c}\text { Mean }(n) \\
\text { (Item } \\
\text { Mean) }\end{array}$ & $\begin{array}{l}\text { Mean }(n) \\
\text { (Item } \\
\text { Mean) }\end{array}$ & $\begin{array}{c}\text { Mean }(n) \\
\text { (Item } \\
\text { Mean) }\end{array}$ & $\begin{array}{c}\text { Mean }(n) \\
(\text { Item } \\
\text { Mean) }\end{array}$ & $\begin{array}{l}\text { Mean }(n) \\
\text { (Item } \\
\text { Mean) }\end{array}$ & & \\
\hline $\begin{array}{l}\text { Cognitive } \\
\text { Outcomes } \\
(6 \text { items })\end{array}$ & $\begin{array}{c}14.6(6) \\
(2.4)\end{array}$ & $\begin{array}{c}14.7(8) \\
(2.4)\end{array}$ & $\begin{array}{c}13.8(34) \\
(2.3)\end{array}$ & $\begin{array}{c}12.8(7) \\
(2.1)\end{array}$ & $\begin{array}{l}13(8) \\
(2.1)\end{array}$ & $\begin{array}{c}10(10) \\
(1.6)\end{array}$ & $\begin{array}{c}11.3(16) \\
(1.8)\end{array}$ & 1.6 & .14 \\
\hline $\begin{array}{l}\text { Characteristic } \\
\text { s of SLOs } \\
\text { (13 items) }\end{array}$ & $\begin{array}{l}34(7) \\
(2.6)\end{array}$ & $\begin{array}{c}28.2(8) \\
\quad(2.1)\end{array}$ & $\begin{array}{c}30.6_{a}(34) \\
\quad(2.3)\end{array}$ & $\begin{array}{c}25.4(7) \\
(1.9)\end{array}$ & $\begin{array}{c}33.5 \mathrm{~b}(7) \\
(2.5)\end{array}$ & $\begin{array}{c}24.5(12) \\
\quad(1.8)\end{array}$ & $\begin{array}{c}21.9_{\mathrm{ab}}(13) \\
(1.6)\end{array}$ & $3.0^{*}$ & .23 \\
\hline $\begin{array}{l}\text { Direct } \\
\text { Methods } \\
\text { (9 items) }\end{array}$ & $\begin{array}{c}7.4(7) \\
(.82)\end{array}$ & $\begin{array}{c}14.3(8) \\
(1.5)\end{array}$ & $\begin{array}{c}11.8(28) \\
\quad(1.3)\end{array}$ & $\begin{array}{c}17.7(7) \\
(1.9)\end{array}$ & $\begin{array}{c}11.2(7) \\
(1.2)\end{array}$ & $\begin{array}{c}12.6(9) \\
(1.4)\end{array}$ & $\begin{array}{c}7.6(14) \\
(.8)\end{array}$ & 2.5 & .20 \\
\hline $\begin{array}{l}\text { Indirect } \\
\text { Methods } \\
\text { (12 items) }\end{array}$ & $\begin{array}{c}29.8(6) \\
(2.4)\end{array}$ & $\begin{array}{c}25.7(8) \\
(2.1)\end{array}$ & $\begin{array}{l}28.4(33) \\
\quad(2.3)\end{array}$ & $\begin{array}{c}23.2(7) \\
(1.9)\end{array}$ & $\begin{array}{c}27.4(7) \\
(2.2)\end{array}$ & $\begin{array}{c}22(9) \\
(1.8)\end{array}$ & $\begin{array}{c}26.8(15) \\
\quad(2.2)\end{array}$ & 1.4 & .13 \\
\hline $\begin{array}{l}\text { Utilize } \\
\text { Results } \\
\text { (8 items) }\end{array}$ & $\begin{array}{c}21_{\mathrm{ab}}(7) \\
(2.6)\end{array}$ & $\begin{array}{c}18.1(8) \\
(2.2)\end{array}$ & $\begin{array}{c}17.1(33) \\
(2.1)\end{array}$ & $\begin{array}{c}12.8_{a}(7) \\
(1.6)\end{array}$ & $\begin{array}{c}17.5(8) \\
(2.1)\end{array}$ & $\begin{array}{c}11.8_{\mathrm{b}}(12) \\
(1.3)\end{array}$ & $\begin{array}{c}14.6(16) \\
(1.8)\end{array}$ & $3.8 * *$ & .28 \\
\hline
\end{tabular}

Note. Based on Tukey multiple comparison tests, means with the same alphabetical subscripts are significantly different from each other.

Note. $* p<.05 . * * p<.01$ 


\section{Research Question Five}

\section{Is there a statistically significant difference in the extent to which undergraduate} communication studies departments communicate their results to different audiences that vary according to different institution types (Carnegie Foundation for the Advancement of Teaching, 2000)?
a. Doctoral/Research Universities-Extensive and Intensive
b. Master's Colleges and Universities I and II
c. Baccalaureate Colleges-Liberal Arts and General
d. Associates Colleges

Three Analyses of Variance (ANOVAs) were computed to determine if there were differences in how and to whom undergraduate communication studies programs were communicating their assessment results based on their Carnegie Classification. For these analyses, institution type served as the independent variable, while the sum of questions 57 through 60 (Internal Assessment Audiences), 61 through 64 (External Assessment Audiences) and 66 through 72 (Methods of Dissemination) represented the dependent variables. As discussed previously, respondents chose the most appropriate response for each individual item ranging from very often (1) to never (5). For the purposes of this study, a lower categorical sum represents a higher frequency of activity.

Results of the ANOVA computed to examine Internal Assessment Audiences indicated that there were no significant differences in the extent to which respondents communicated assessment results to internal audiences $(F(6,81)=1.77, p=.12)$ (see Table 20). The ANOVA computed to examine External Assessment Audiences was significant $(F(6,82)=2.9, p=.014)$ (see Table 21). A closer examination of the ANOVA using a Tukey Multiple Comparison test 
revealed that BA General institutions $(M=14.4)$ significantly more often communicated assessment results to external audiences than Masters I institutions $(M=17.3)$.

The ANOVA conducted on Methods of Dissemination of Assessment Results revealed a significant model $(F(6,80)=2.42, p=.04)$. A closer examination of the ANOVA using a Tukey multiple comparison test revealed that there were no significant differences in the multi comparison tests (see Table 22). This finding is most likely due to the small sample size within each of the Carnegie Classifications.

Table 20

Analysis of Variance for Communication of Assessment to Internal Audiences by Institution Type

\begin{tabular}{|c|c|c|c|c|c|c|c|c|c|}
\hline & $\begin{array}{l}\text { Doctoral } \\
\text { Extensive }\end{array}$ & $\begin{array}{l}\text { Doctoral } \\
\text { Intensive }\end{array}$ & $\begin{array}{c}\text { Masters } \\
\text { I }\end{array}$ & $\begin{array}{l}\text { Masters } \\
\text { II }\end{array}$ & $\begin{array}{c}\text { BA } \\
\text { Liberal } \\
\text { Arts }\end{array}$ & $\begin{array}{c}\text { BA } \\
\text { General }\end{array}$ & Associates & \multirow{3}{*}{$F$} & \multirow{3}{*}{ eta $^{2}$} \\
\hline & $n=7$ & $n=8$ & $n=33$ & $n=6$ & $n=7$ & $n=11$ & $n=16$ & & \\
\hline & $\begin{array}{l}\text { Mean } \\
\text { (Item } \\
\text { Mean) }\end{array}$ & $\begin{array}{l}\text { Mean } \\
\text { (Item } \\
\text { Mean) }\end{array}$ & $\begin{array}{l}\text { Mean } \\
\text { (Item } \\
\text { Mean) }\end{array}$ & $\begin{array}{l}\text { Mean } \\
\text { (Item } \\
\text { Mean) }\end{array}$ & $\begin{array}{l}\text { Mean } \\
\text { (Item } \\
\text { Mean) }\end{array}$ & $\begin{array}{l}\text { Mean } \\
\text { (Item } \\
\text { Mean) }\end{array}$ & $\begin{array}{l}\text { Mean } \\
\text { (Item } \\
\text { Mean) }\end{array}$ & & \\
\hline $\begin{array}{l}\text { Internal } \\
\text { Audience } \\
\text { (4 items) }\end{array}$ & $\begin{array}{l}12.1 \\
(3.0)\end{array}$ & $\begin{array}{l}10.6 \\
(2.6)\end{array}$ & $\begin{array}{l}11.5 \\
(2.8)\end{array}$ & $\begin{array}{l}10.1 \\
(2.5)\end{array}$ & $\begin{array}{c}12 \\
(3.0)\end{array}$ & $\begin{array}{l}9.5 \\
(2.3)\end{array}$ & $\begin{array}{c}9.5 \\
(2.3)\end{array}$ & 1.76 & .125 \\
\hline
\end{tabular}


Table 21

Analysis of Variance for Communication of Assessment to External Audiences by Institution Type

\begin{tabular}{|c|c|c|c|c|c|c|c|c|c|}
\hline & $\begin{array}{l}\text { Doctoral } \\
\text { Extensive }\end{array}$ & $\begin{array}{l}\text { Doctoral } \\
\text { Intensive }\end{array}$ & $\begin{array}{c}\text { Masters } \\
\text { I }\end{array}$ & $\begin{array}{c}\text { Masters } \\
\text { II }\end{array}$ & $\begin{array}{c}\text { BA } \\
\text { Liberal } \\
\text { Arts }\end{array}$ & $\begin{array}{c}\text { BA } \\
\text { General }\end{array}$ & Associates & \multirow{3}{*}{$F$} & \multirow{3}{*}{$e t a$} \\
\hline & $n=7$ & $n=8$ & $n=34$ & $n=7$ & $n=7$ & $n=10$ & $n=16$ & & \\
\hline & $\begin{array}{c}\text { Mean } \\
\text { (Item } \\
\text { Mean) }\end{array}$ & $\begin{array}{l}\text { Mean } \\
\text { (Item } \\
\text { Mean) }\end{array}$ & $\begin{array}{l}\text { Mean } \\
\text { (Item } \\
\text { Mean) }\end{array}$ & $\begin{array}{c}\text { Mean } \\
\text { (Item } \\
\text { Mean) }\end{array}$ & $\begin{array}{c}\text { Mean } \\
\text { (Item } \\
\text { Mean) }\end{array}$ & $\begin{array}{l}\text { Mean } \\
\text { (Item } \\
\text { Mean) }\end{array}$ & $\begin{array}{l}\text { Mean } \\
\text { (Item } \\
\text { Mean) }\end{array}$ & & \\
\hline $\begin{array}{l}\text { External } \\
\text { Audience } \\
\text { (4 items) }\end{array}$ & $\begin{array}{l}17.4 \\
(4.3)\end{array}$ & $\begin{array}{l}16.6 \\
(4.1)\end{array}$ & $\begin{array}{l}17.3 \mathrm{a} \\
(4.3)\end{array}$ & $\begin{array}{l}15.8 \\
(3.9)\end{array}$ & $\begin{array}{l}15.8 \\
(3.9)\end{array}$ & $\begin{array}{l}14.4 \mathrm{a} \\
(3.6)\end{array}$ & $\begin{array}{l}14.8 \\
(3.7)\end{array}$ & $2.88^{*}$ & .19 \\
\hline
\end{tabular}

Note. Based on a Tukey multiple comparison test, means with the same alphabetical subscripts are significantly different from each other.

Note. $* p<.05 . * * p<.01$

Table 22

Analysis of Variance for Dissemination of Assessment Results by Institution Type

\begin{tabular}{|c|c|c|c|c|c|c|c|c|c|}
\hline & $\begin{array}{l}\text { Doctoral } \\
\text { Extensive }\end{array}$ & $\begin{array}{l}\text { Doctoral } \\
\text { Intensive }\end{array}$ & $\begin{array}{c}\text { Masters } \\
\text { I }\end{array}$ & $\begin{array}{c}\text { Masters } \\
\text { II }\end{array}$ & $\begin{array}{c}\text { BA } \\
\text { Liberal } \\
\text { Arts } \\
\end{array}$ & $\begin{array}{c}\text { BA } \\
\text { General }\end{array}$ & Associates & \multirow{3}{*}{$F$} & \multirow{3}{*}{$e t a^{2}$} \\
\hline & $n=7$ & $n=8$ & $n=33$ & $n=7$ & $n=8$ & $n=10$ & $n=14$ & & \\
\hline & $\begin{array}{c}\text { Mean } \\
\text { (Item } \\
\text { Mean) }\end{array}$ & $\begin{array}{l}\text { Mean } \\
\text { (Item } \\
\text { Mean) }\end{array}$ & $\begin{array}{l}\text { Mean } \\
\text { (Item } \\
\text { Mean) }\end{array}$ & $\begin{array}{l}\text { Mean } \\
\text { (Item } \\
\text { Mean) } \\
\end{array}$ & $\begin{array}{l}\text { Mean } \\
\text { (Item } \\
\text { Mean) } \\
\end{array}$ & $\begin{array}{l}\text { Mean } \\
\text { (Item } \\
\text { Mean) } \\
\end{array}$ & $\begin{array}{c}\text { Mean } \\
\text { (Item } \\
\text { Mean) }\end{array}$ & & \\
\hline $\begin{array}{l}\text { Dissemination } \\
\text { of Results } \\
\text { (8 items) }\end{array}$ & $\begin{array}{l}26.8 \\
(3.3)\end{array}$ & $\begin{array}{l}25.7 \\
(3.2)\end{array}$ & $\begin{array}{l}28.8 \\
(3.6)\end{array}$ & $\begin{array}{c}24.0 \\
(3)\end{array}$ & $\begin{array}{l}26.5 \\
(3.3)\end{array}$ & $\begin{array}{l}23.4 \\
(2.9)\end{array}$ & $\begin{array}{l}23.5 \\
(2.9)\end{array}$ & 2.41 & .16 \\
\hline
\end{tabular}




\section{Research Question Six}

6. Is there a statistically significant difference in the extent to which institutional resources are available to undergraduate communication studies departments for program assessment that vary according to different institution types (Carnegie Foundation for the Advancement of Teaching, 2000)?
a. Doctoral/Research Universities-Extensive and Intensive
b. Master's Colleges and Universities I and II
c. Baccalaureate Colleges-Liberal Arts and General
d. Associates Colleges

Three ANOVAs were computed to determine if there were differences in how institutions support departmental assessment efforts and how faculty were rewarded for assessment efforts in undergraduate communication studies programs based on their Carnegie Classification. For this analysis, institution type served as the independent variable, while the sum of questions 74 through 77 (Institutional Support for Assessment), 87 through 93 (Faculty Incentives for Assessment), and 96 through 105 (Faculty Benefits of Assessment) represented the three dependent variables. Items investigating Institutional Support and Faculty Benefits for Assessment allowed respondents to choose the most appropriate response for each individual item ranging from very often (1) to never (5). For items investigating Faculty Incentives for Assessment respondents were asked to indicate the frequency of incentives offered to faculty for incentives' from every semester (1) to never (6). For the purpose of this study, a lower categorical sum represents a higher frequency of activity.

Results of the ANOVA conducted to examine Institutional Support for Assessment efforts was not significant $(F(6,86)=1.6, p=.171)$ (see Table 23). However, the ANOVAs 
conducted to examine Faculty Incentives for Assessment $(F(6,70)=2.4, p=.038)$ and Faculty Benefits of Assessment $(F(6,73)=3.36, p=.006)$ did reveal significant models.

Due to evidence of significant models, Tukey multiple comparison tests were utilized to more closely examine the differences between institution types with regard to faculty incentives and benefits for utilizing assessment. There was a significant difference in Faculty Incentives for Assessment between Associates $(M=32.1)$ and Doctoral Extensive $(M=42)$ institutions. Associates institutions reported more incentives provided for assessment efforts than Doctoral Extensive institutions (see Table 24).

The Tukey multiple comparison test conducted to further examine Faculty Benefits for Assessment revealed that there was a significant difference between Associates $(M=29.8)$ institutions and both Doctoral Extensive $(M=43.5)$ and Masters I $(M=39.42)$ institutions. Respondents from Associates institutions indicated significantly more benefits for assessment efforts than Doctoral Extensive and Masters I institutions (see Table 25). 
Table 23

Analysis of Variance for Support for Assessment by Institution Type

\begin{tabular}{|c|c|c|c|c|c|c|c|c|c|}
\hline & $\begin{array}{l}\text { Doctoral } \\
\text { Extensive }\end{array}$ & $\begin{array}{l}\text { Doctoral } \\
\text { Intensive }\end{array}$ & $\begin{array}{c}\text { Masters } \\
\text { I }\end{array}$ & $\begin{array}{c}\text { Masters } \\
\text { II }\end{array}$ & $\begin{array}{c}\text { BA } \\
\text { Liberal } \\
\text { Arts }\end{array}$ & $\begin{array}{c}\text { BA } \\
\text { General }\end{array}$ & Associates & \multirow[t]{3}{*}{$F$} & \multirow[t]{3}{*}{$e t a^{2}$} \\
\hline & $n=7$ & $n=8$ & $n=34$ & $N=7$ & $n=8$ & $n=12$ & $n=17$ & & \\
\hline & $\begin{array}{c}\text { Mean } \\
\text { (Item } \\
\text { Mean) }\end{array}$ & $\begin{array}{c}\text { Mean } \\
\text { (Item } \\
\text { Mean) }\end{array}$ & $\begin{array}{c}\text { Mean } \\
\text { (Item } \\
\text { Mean) }\end{array}$ & $\begin{array}{c}\text { Mean } \\
\text { (Item } \\
\text { Mean) }\end{array}$ & $\begin{array}{c}\text { Mean } \\
\text { (Item } \\
\text { Mean) }\end{array}$ & $\begin{array}{c}\text { Mean } \\
\text { (Item } \\
\text { Mean) }\end{array}$ & $\begin{array}{c}\text { Mean } \\
\text { (Item } \\
\text { Mean) }\end{array}$ & & \\
\hline $\begin{array}{l}\text { Support } \\
(4 \\
\text { items) }\end{array}$ & $\begin{array}{l}14.5 \\
(3.6)\end{array}$ & $\begin{array}{l}11.4 \\
(2.8)\end{array}$ & $\begin{array}{l}12.0 \\
(3.0)\end{array}$ & $\begin{array}{l}10.0 \\
(2.5)\end{array}$ & $\begin{array}{l}12.8 \\
(3.2)\end{array}$ & $\begin{array}{l}10.4 \\
(2.6)\end{array}$ & $\begin{array}{c}8.6 \\
(2.1)\end{array}$ & 1.57 & .136 \\
\hline
\end{tabular}

Table 24

Analysis of Variance for Faculty Incentives of Assessment by Institution Type

\begin{tabular}{|c|c|c|c|c|c|c|c|c|c|}
\hline & $\begin{array}{c}\text { Doctoral } \\
\text { Extensive }\end{array}$ & $\begin{array}{l}\text { Doctoral } \\
\text { Intensive }\end{array}$ & $\begin{array}{c}\text { Masters } \\
\text { I }\end{array}$ & $\begin{array}{c}\text { Masters } \\
\text { II }\end{array}$ & $\begin{array}{c}\text { BA } \\
\text { Liberal } \\
\text { Arts }\end{array}$ & $\begin{array}{c}\text { BA } \\
\text { General }\end{array}$ & Associates & $F$ & $e t a^{2}$ \\
\hline & $\begin{array}{c}n=6 \\
\text { Mean } \\
\text { (Item } \\
\text { Mean) }\end{array}$ & $\begin{array}{c}n=7 \\
\text { Mean } \\
\text { (Item } \\
\text { Mean) }\end{array}$ & $\begin{array}{l}n=32 \\
\text { Mean } \\
\text { (Item } \\
\text { Mean) }\end{array}$ & $\begin{array}{c}n=6 \\
\text { Mean } \\
\text { (Item } \\
\text { Mean) }\end{array}$ & $\begin{array}{c}n=6 \\
\text { Mean } \\
\text { (Item } \\
\text { Mean) }\end{array}$ & $\begin{array}{l}n=9 \\
\text { Mean } \\
\text { (Item } \\
\text { Mean) }\end{array}$ & $\begin{array}{l}n=11 \\
\text { Mean } \\
\text { (Item } \\
\text { Mean) }\end{array}$ & & \\
\hline $\begin{array}{l}\text { Faculty } \\
\text { Incentives } \\
\text { (7 items) }\end{array}$ & $\begin{array}{c}42_{\mathrm{a}} \\
(6.0)\end{array}$ & $\begin{array}{l}35.2 \\
(5.0)\end{array}$ & $\begin{array}{l}28.7 \\
(4.1)\end{array}$ & $\begin{array}{l}35.1 \\
(5.0)\end{array}$ & $\begin{array}{l}38.4 \\
(5.4)\end{array}$ & $\begin{array}{l}36.7 \\
(5.2)\end{array}$ & $\begin{array}{l}32.1_{\mathrm{a}} \\
(4.5)\end{array}$ & $2.4^{*}$ & .194 \\
\hline
\end{tabular}

Note. Based on a Tukey multiple comparison test, means with the same alphabetical subscripts are significantly different from each other.

Note. $* p<.05 . * * p<.01$ 
Table 25

Analysis of Variance for Faculty Benefits of Assessment by Institution Type

\begin{tabular}{|c|c|c|c|c|c|c|c|c|c|}
\hline & $\begin{array}{c}\text { Doctoral } \\
\text { Extensive }\end{array}$ & $\begin{array}{l}\text { Doctoral } \\
\text { Intensive }\end{array}$ & $\begin{array}{c}\text { Masters } \\
\text { I }\end{array}$ & $\begin{array}{c}\text { Masters } \\
\text { II }\end{array}$ & $\begin{array}{c}\text { BA } \\
\text { Liberal } \\
\text { Arts }\end{array}$ & $\begin{array}{c}\text { BA } \\
\text { General }\end{array}$ & Associates & $F$ & $\mathrm{eta}^{2}$ \\
\hline & $n=7$ & $n=8$ & $n=30$ & $N=7$ & $n=7$ & $n=7$ & $n=14$ & & \\
\hline & $\begin{array}{c}\text { Mean } \\
\text { (Item } \\
\text { Mean) }\end{array}$ & $\begin{array}{l}\text { Mean } \\
\text { (Item } \\
\text { Mean) }\end{array}$ & $\begin{array}{c}\text { Mean } \\
\text { (Item } \\
\text { Mean) }\end{array}$ & $\begin{array}{c}\text { Mean } \\
\text { (Item } \\
\text { Mean) }\end{array}$ & $\begin{array}{c}\text { Mean } \\
\text { (Item } \\
\text { Mean) }\end{array}$ & $\begin{array}{c}\text { Mean } \\
\text { (Item } \\
\text { Mean) }\end{array}$ & $\begin{array}{c}\text { Mean } \\
\text { (Item } \\
\text { Mean) }\end{array}$ & & \\
\hline $\begin{array}{l}\text { Faculty } \\
\text { Benefits } \\
(10 \\
\text { items })\end{array}$ & $\begin{array}{c}43.5_{a} \\
(4.3)\end{array}$ & $\begin{array}{l}32.5 \\
(3.2)\end{array}$ & $\begin{array}{l}39.4_{\mathrm{b}} \\
(3.9)\end{array}$ & $\begin{array}{c}31 \\
(3.1)\end{array}$ & $\begin{array}{l}28.6 \\
(2.8)\end{array}$ & $\begin{array}{l}37.4 \\
(3.7)\end{array}$ & $\begin{array}{c}29.8_{\mathrm{ab}} \\
(2.9)\end{array}$ & $3.3 *$ & .251 \\
\hline
\end{tabular}

Note. Based on a Tukey multiple comparison test, means with the same alphabetical subscripts are significantly

different from each other.

Note. $* p<.05 . * * p<.01$

This chapter reviewed the results of each research question put forth in this study. Research questions were paired with their corresponding survey items, detailing analyses conducted and results answering each question. Comprehensive results of the research questions presented in this study were displayed in tabular format. The following chapter will discuss conclusions based on the results of the study and implications for future research and practice. 


\section{CHAPTER 5: CONCLUSION AND IMPLICATIONS}

Previous chapters established a need for quality program-level assessment in higher education. Clark (2002) discussed the necessity and importance of examining instructional practices and particularly assessment in communication studies programs. Most studies on assessment in the field of Communication Studies have been limited to single case studies of academic departments. There has been no recent comprehensive overview of the general state of assessment in undergraduate communication studies programs in the United States. The purpose of this study was to gather descriptive data on contemporary departments of communication studies' assessment practices at different institutions. This chapter will consider the results of this study, describing the extent to which communication studies departments are implementing program-level assessments. Assessment processes, student learning outcomes, assessment methods, use and communication of assessment results, and faculty incentives and resources for conducting assessments will be discussed in hopes of establishing a baseline of assessment practices in undergraduate communication studies programs for future investigations.

\section{Assessment Process}

According to Hatfield (1999), many academic departments undertake minimal assessment efforts simply to satisfy administrators' requests. This effort typically results in a snapshot view of the curriculum through a review process every three to five year. Hatfield argued that a snapshot is not an accurate view of the functioning of that department. Data provided from the respondents in this study indicate that most respondents have not only implemented an assessment plan, but actually utilized assessment as a process and a tool for curriculum change and accreditation. Results from this study suggest that survey respondents 
view assessment as a routine activity that serves as a process for curriculum change as well as accreditation.

It also is interesting to note that the majority of study participants responded that assessment data were collected and analyzed often or very often. Respondents believed assessment focuses on student learning. They did not see it as a tool to simply satisfy accreditation or administrative mandates. Only eleven percent of respondents indicated that assessment data were never collected.

These results seem to indicate that the respondents of this study have an accurate view of the function of assessment. They reported collecting and utilizing the data for continuous improvement, suggesting that there is a positive climate for assessment in the field of communication studies (Peterson \& Einarson, 2001).

\section{Student Learning Outcomes}

Huba and Freed (2000) operationalized assessment, as a four step process that must begin with the establishment of learning goals. Hay (1992) expressed concern that only $30 \%$ of communication departments had defined departmental student learning objectives. Respondents from this study now appear to be in line with many necessary characteristics for effective assessments, including the definition of student learning objectives. Most departments indicated that their SLOs are developed often or very often in accordance with their program mission and are relevant to the discipline of communication studies. Respondents stated that SLOs are clear and are typically shared with faculty in accordance with the principles of good practice according to the American Association of Higher Education (1992).

However, barely half of respondents indicated that they often or very often shared their SLOs with their students or pre-students. In fact, $61 \%$ of respondents indicated that their students 
were aware of departmental SLOs at graduation. While this number may seem encouraging, student awareness of departmental goals is a basic and vital first step in student learning. According to the American Association of Higher Education (1992), it is essential that learning outcomes are clear, understandable, and visible to all program constituents. Potential and current students must have a clear understanding of program learning outcomes to make an informed major choice and appropriately focus their education and career goals. Chairs responding that students are not informed of SLOs indicates a serious problem with the critical step of clearly communicating student learning outcomes to students as they are progressing through their respective programs.

It is encouraging that communication studies departments are now clearly establishing learning goals. However, these learning goals must be shared with all constituents, including students, if they are to be effective.

\section{Assessment Methods}

According to Palomba and Banta (1999), both direct and indirect assessments are necessary to demonstrate student achievement of intended learning outcomes. These results indicated that respondents utilized assessment methods through course embedded assignments, essays, and faculty designed tests throughout the program. However, direct assessments were primarily utilized in students' final years in school through internships, portfolios, and capstone projects. These direct assessments require students to demonstrate their use of knowledge rather than declare their perceptions of their knowledge (Allen, 2004).

Concerning indirect assessment, many respondents indicated they have completed indirect assessments. The most frequent types were alumni and student surveys. Most departments indicated that they performed indirect assessments once a year. 
Respondents indicated that course embedded assignments, essays and faculty designed tests were direct assessments utilized throughout schooling. Because additional information about these measures was not collected, it is not clear what these assessments entailed and whether they are truly direct assessments. Indisputable direct measures of learning such as capstone courses, portfolios and internships, were heavily loaded in students' junior and senior years. If assessment is to be an ongoing process used for student learning, it must be prevalent throughout the program, not just immediately prior to completion of the program. Obtaining direct assessment results as a student progresses through the program enables faculty to measure what is being learned in order to make adjustments to the curriculum. In other words, communication departments, while they are using both direct and indirect methods of assessment, may not be implementing assessment practices throughout the curriculum. This is necessary to fully reap the benefits of assessment for students.

\section{Use of Assessment Results}

Using assessment results for continuous improvement is the final step in a comprehensive assessment plan (Suskie, 2004). Respondents indicated that they very often or often used assessment results to make curricular changes, program planning and decision making, and improving student learning. Assessment data is utilized by $62.7 \%$ of respondents at least sometimes for determining resource allocation. Respondents, according to the results, understand and are using assessment for its intended purpose. Respondents claimed to be using assessment as a vehicle to enhance their program, not simply to satisfy accreditation or administration requirements. However, as mentioned above, assessing students primarily in their final years in school does not allow a clear picture of the first few years of students' education. 


\section{Communication of Assessment Results}

According to the American Association of Higher Education (1992), it is imperative to inform all constituents of assessment results in order to gain various perspectives on how student learning can be improved. Survey respondents indicated that they communicated assessment results to faculty and administrators through accreditation or governance board reports. However, assessment results were rarely discussed with students, parents or alumni organizations. If this information is shared with additional constituents, it might serve as an impetus to gain additional feedback for assessment methods or program review.

\section{Faculty Rewards and Resources}

According to Allen (2004), there is a need for faculty rewards and incentives to encourage comprehensive assessment practices at higher learning institutions. Results of this research study indicated that communication studies department chairs perceived support from administrators for assessment efforts. However, administrators rarely allocated resources for implementing or maintaining assessment efforts. Department chairs reported that faculty rarely, if ever, received incentives for assessment efforts. Interestingly, $62.7 \%$ of program chairs indicated that they utilized assessment results to determine resource allocation. These resources, however, do not appear to funnel into faculty support for assessment efforts. In fact, most departments indicated that faculty never received time, grants, stipends, graduate assistants or travel support for assessment efforts. In addition, $45 \%$ of department chairs indicated that assessment efforts are not recognized in the promotion and tenure process. With regard to the discipline of communication studies, $90 \%$ of chairs reported that faculty rarely or never publish assessment results in journals or books. Presentations of assessment practices and results are rarely or never presented at national conferences according to over $70 \%$ of department chairs. 
This finding suggests that while administrators vocalize their support for assessment, they do not always follow through with support, monetarily or otherwise, to ensure that quality, comprehensive assessment is actually taking place.

\section{Carnegie Classification}

Peterson and Einarson (2001) discussed the vital role that institutional climate and culture play in the promotion and utilization of student assessment to improve academic program performance. An institution's Carnegie Classification may significantly impact its climate and culture with regard to assessment of student learning. For example, Peterson and Einarson asserted that the nature of research institutions may challenge the value of current assessment mandates. Departments and faculty in large research institutions tend to act autonomously, selfgoverning their scholarship and teaching. Directives enforcing assessment may be considered an inconvenience and burden to a department if research is thought to be its primary objective (Peterson \& Einarson, 2001).

One goal of this study was to determine if there are differences in the extent to which undergraduate communication studies programs are implementing their assessment plans based on their Carnegie Classification. An examination of the results indicates that while some differences appear to exist between the various Carnegie Classifications, these differences failed to reach a level of statistical significance. However, the lack of statistically significant differences could be an artifact of the small sample size within each institution type.

Despite the small number of respondents from each institution type, some significant differences were found. Associate Colleges were found to align their student learning outcomes more closely with the principles of good practice put forth by the American Association of Higher Education (1992) than Liberal Arts or Masters I institutions. In addition, a significant 
difference was found in the extent to which Doctoral Extensive institutions utilized assessment results to make program improvements compared to BA General or Masters II institutions. The latter groups more thoroughly utilized assessment results to develop their undergraduate programs. This finding is consistent with the assertion made by Peterson and Einarson (2001) concerning the research focus at doctoral institutions. Faculty at research institutions tend to be rewarded for conducting research rather than emphasizing student learning.

Some differences also were found in the extent to which resources are available to undergraduate communication studies departments based on Carnegie Classification. Again, many of these differences failed to reach a level of statistical significance due to the small sample size within each institution type. There were not significant differences in institutional support for assessment efforts based on institution type. However, faculty incentives for assessment and faculty benefits of assessment did reveal significant differences. Associates institutions reported that faculty received more benefits for assessment efforts than Doctoral Extensive or Masters I institutions.

It is not surprising that Associates institutions reward assessment more than Doctoral Extensive and Masters I institutions. Again, based on the Peterson and Einarson (2001) assertion, institutions with significant graduate programs (such as Doctoral Extensive and Masters I institutions) historically place more emphasis on research, resulting in less administrative support for other areas such as student learning and assessment.

\section{Recommendations for Practice}

Specific results examined in this study are cause for concern, and require adjustments in current assessment practices. Results indicating that almost $40 \%$ percent of respondents reported that their students are not aware of student learning outcomes are disturbing. Again, awareness of 
SLOs is a vital step in student learning. To improve assessment practices in communication studies, departments should clarify and publicize their intended student learning outcomes for pre-majors and majors through departmental materials, course syllabi, course catalogues, and advising. This publicity will allow students to have a clear understanding of what their intended major entails prior to fully committing to it. More importantly, it will enhance learning for communication majors by clearly stating what faculty intend for them to learn, shaping their understanding of the field, and illuminating career goals and objectives relevant to their major. Departments of communication studies must publicize their intended learning outcomes to students via advising, departmental materials, and courses to increase student learning and student satisfaction of their major choice.

There seems to be an emphasis on both direct and indirect assessments in communication studies, according to survey respondents. According to responding department chairs, indisputable direct assessments were applied primarily in students' final years of schooling. Many respondents indicated that course embedded assignments, faculty designed tests and essays were direct demonstrations that were utilized in students' final years. However, it is unclear whether the methods used are actually direct assessments. Consequently this is an area that requires more research to determine if communication studies chairs' current understanding of direct methods are accurate.

Direct demonstrations of student learning should be evaluated throughout the degree program. As part of a comprehensive assessment program, assessment results should be used to make curricular changes, program planning, and decision making and program improvements. If direct measures of student learning are only examined at the end of the program, the first few years of education are discounted. To accurately understand and incorporate assessment results 
into the curriculum, departments need a thorough picture of student learning, not just in the final years. Departments of communication studies need to ensure that direct assessments of student learning throughout their curriculum are implemented so that true assessment can occur.

It is vital to the assessment process to not only incorporate assessment results into the curriculum, but to then communicate those assessment results to a variety of constituencies (AAHE, 1992). Survey respondents indicated that faculty and administrators are the primary audiences that receive this information. Additional constituencies such as parents, students and alumni are not informed of assessment results. To gain various perspectives on how student learning can be improved, communication studies departments must share this information with students, parents, and alumni. These are the constituencies that experience and benefit from the program, and therefore have an enormous stake in its success. Although often overlooked, these audiences are a valuable resource for advice and guidance to make program changes and improvements that should be examined by communication studies departments.

The most valuable resource for assessment, in many respects, is departmental faculty. Investing in faculty assessment efforts is vital to promoting a culture of assessment. However, faculty rewards and incentives for assessment efforts is an area lacking based on respondents from departments of communication studies. Department chairs indicated that resources have been allocated based on assessment results, but these resources do not appear to support future assessment efforts. Vocalizing support for these efforts, as indicated by the survey results, is a start, but it is not enough.

According to department chairs, letters of commendation, expressions of gratitude (both personal and public), or interactions with faculty at other institutions are not provided to faculty for their assessment efforts. Comprehensive assessment for continuous improvement is a time 
intensive venture. However, department chairs indicated that assessment efforts are not recognized in the promotion and tenure process. With regard to the discipline of communication studies, most chairs reported that faculty rarely or never publish assessment results in journals or books. Presentations of assessment practices and results are rarely or never presented at national conferences.

Institutional climate and culture play a vital role in the promotion and utilization of student assessment to improve academic program performance (Peterson \& Einarson, 2001). The findings reported above demonstrate that faculty are not adequately recognized within their departments or in their field for assessment efforts. If the climate of assessment is to be enhanced, there must be visible, tangible incentives for faculty to invest in assessment efforts.

At the administrative level, training chairs to recognize and adhere to good assessment practices and promoting meaningful incentives for faculty would be a first step for improving the climate of assessment in departments of communication studies. Then, faculty must be trained to understand comprehensive assessment and its positive impact on student learning. A thorough understanding of the benefits may foster internal motivation to adopt comprehensive assessment practices in their teaching.

Additionally, faculty must be compensated for the time and energy they put into assessment. This investment should result an enhanced curriculum, furthering student learning. Small investments for faculty assessment incentives would improve the assessment climate in departments of communication studies. For example, including assessment efforts in the promotion and tenure process, encouraging faculty to publish and present assessment results at conferences, offering release time from teaching, small grants, graduate assistants, or stipends 
may serve as worthwhile strategies for improving assessment efforts, resulting in an increase in student learning.

This culture also must start with the field. The field of communication studies rewarding assessment efforts though encouraging publication of results and practices in journals and presentations at conferences will prompt departments to further recognize the value of this research, increasing the climate of assessment and enhancing student learning in the field as a result.

The previous section discussed implications for practice. It is recommended that departments of communication studies emphasize intended learning outcomes to students, focus direct assessment methods throughout the curriculum and communicate assessment results to all constituencies including students, parents and alumni. To have a serious assessment culture, department chairs and faculty in the field of communication studies must recognize the value and invest in and benefit from incentives for faculty assessment efforts.

\section{Recommendations for Future Research}

Implications for further research based on the current findings are broad. It is encouraging to note that the majority of departments surveyed in this study view assessment as a process for continuous improvement of the curriculum to enhance student learning. In addition, most respondents have a clear understanding of the importance of developing and adhering to student learning outcomes with regard to the curriculum. However, more research and a greater participation rate are necessary to determine how to improve the climate of assessment in departments of communication studies.

A strong limitation in assessment practices is a lack of a culture of assessment (Peterson and Einarson, 2001). Subsequent investigations are necessary to determine how to encourage 
administrators to invest in faculty incentives and rewards for assessment to make it an extrinsically worthwhile pursuit.

Additional research is needed to understand and clarify the extent to which communication studies departments vary in their assessment efforts based on their Carnegie Classifications. Due to the small sample size of this study, the differences in assessment practices found between Carnegie Classifications failed to reach a level of statistical significance. However, further exploration of these differences may reveal a deeper understanding of the effect of climate and culture on assessment practices in higher education institutions. In addition, Associates institutions require further examination. Items designed for this survey were geared for four year programs, and therefore may not fully reflect the assessment efforts of two-year institutions. A survey designed primarily for communication departments in Associates institutions would more clearly expose the particular assessment strengths and challenges faced by two year programs.

Finally, a qualitative review of the best practices of communication studies departments is necessary. Examining departments engaging in comprehensive assessment across all Carnegie Classifications would be an invaluable resource for educating the discipline on the value of and processes for ensuring comprehensive assessment for all types of institutions. This knowledge will reveal successful strategies in various sizes and types of departments, offering solutions for the challenges and illuminating opportunities in all forms of communication studies programs.

Outcome assessments of academic programs have become increasingly critical in recent years. A continuous process formed to "monitor and improve student learning," true assessment serves to focus institutions of higher education on student learning (Allen, 2004, p. 5). It is vital to understand and explore current assessment practices in departments of communication studies 
to ensure and enhance the quality and future of education in the field. This study represents an initial attempt at establishing a baseline of assessment practices utilized within departments of communication studies. Assessment processes, methods, utilization and communication of assessment results and differences in practice between Carnegie Classifications were explored, with encouraging results. Communication studies departments are fairly progressive with regard to their views and uses of assessment. However, assessment efforts still need to be expanded. Communication studies departments must further invest in their assessment efforts, improving the culture of assessment in the discipline. Additional research must be done to ensure a thorough understanding of assessment practices in undergraduate communication studies programs. 


\section{REFERENCES}

Aitken, J. E. (1994, August). Assessment in specific programs: Employment, program, and course student portfolios in Communication Studies. Paper presented at the meeting of the Speech Communication Summer Conference, Alexandria, VA.

Aitken, J. E., \& Neer, M. (1993, May). Multiple approaches to communication program assessment. Paper presented at the meeting of the International Communication Association, Washington, DC.

Allen, M. J. (2004). Assessing academic programs in higher education. Bolton, MA: Anker.

Allen, T. H. (2002). Charting a communication pathway: Using assessment to guide curriculum development in a re-vitalized general education plan. Communication Education, 51(1), 26-39.

American Association for Higher Education (AAHE). (1992). Principles of good practice for assessing student learning. Retrieved December 10, 2004 from http://www.aahe.org/assessment/principl.htm

Anderson, L. W., Krathwohl, D. R., Airasian, P. W., Cruikshank, K. A., Mayer, R. E., Pintrich, et al. (Eds.). (2001). A taxonomy for learning, teaching, and assessing: A revision of Bloom's Taxonomy of Educational Objectives. New York: Longman.

Banta, T. W., \& Schneider, J. A. (1988). Using faculty-developed exit examinations to evaluate academic programs. The Journal of Higher Education, 59(1), 69-83.

Bentlejewski, J. T. (2003). Utilization of assessment by Maryland Cooperative Extension faculty. Unpublished doctoral dissertation, West Virginia University, Morgantown. 
Carnegie Foundation for the Advancement of Teaching. (2000) The Carnegie Classification of Institutions of Higher Education. Retrieved April 27, 2005 from http://www.carnegiefoundation.org/Classification/

Cheng, D. X. (2001). Assessing student collegiate experience: Where do we begin? Assessment \& Evaluation in Higher Education, 26(6), 525-537.

Clark, R. A. (2002). Learning outcomes: The bottom line. Communication Education, 51(4), 396-404.

Cole, T. W. (1996, March). Evaluating effectiveness through program assessment. Paper presented at the meeting of the Southern States Communication Association, Memphis, TN.

Cook, B. W. (1997). Fundraising and the college presidency in an era of uncertainty. The Journal of Higher Education, 68(1), 53-86.

Craig, R. T., \& Carlone, D. E. (1998). Growth and transformation of communication studies in U.S. higher education: Towards reinterpretation. Communication Education, 47(1), 6781.

Creswell, J. W. (2003). Research design: Qualitative, quantitative, and mixed method approaches. Thousand Oaks, CA: Sage.

Erwin, T. D., \& Wise, S. L. (2002). A scholar-practitioner model for assessment. In T. W. Banta (Ed.), Building a scholarship of assessment (pp. 67-81). San Francisco: Jossey-Bass.

Ewell, P. T. (2002). An emerging scholarship: A brief history of assessment. In T. W. Banta (Ed.), Building a scholarship of assessment (pp. 3-25). San Francisco: Jossey-Bass. 
Friedrich, G. W., \& Boileau, D. M. (1999). The communication discipline. In A. L. Vangelisti, J. A. Daly, \& G. W. Friedrich (Eds.), Teaching communication: Theory, research, and methods (pp. 3-13). Mahwah, NJ: Erlbaum.

Gray, P. J. (2002). The roots of assessment: Tensions, solutions and research directions. In T. W. Banta (Ed.), Building a scholarship of assessment (pp. 49-66). San Francisco: JosseyBass.

Hatfield, S. R. (1999, May). Department level assessment: Promoting continuous improvement. Idea Center, 35.

Hay, E.A. (1992). A national survey of assessment trends in communication departments. Communication Education, 41(3), 247-257.

Huba, M. E., \& Freed, J. E. (2000). Learner centered assessment on college campuses: Shifting the focus from teaching to learning. Boston: Allyn and Bacon.

James, P. (2000). A blueprint for skills assessment in higher education. Assessment \& Evaluation in Higher Education, 25(4), 353-368.

Locke, L. F., Silverman, S. J., \& Spirduso, W. W. (1998). Reading and understanding research. Thousand Oaks, CA: Sage.

Lopez, C. (1999). A decade of assessing student learning: What we have learned; what's next? Retrieved April 12, 2005, from www.ncacihe.org/AnnualMeeting/archive/ASSESS10.PDF

Lusher, A. (2005). Identifying assessment practices in undergraduate accounting programs. Unpublished doctoral dissertation, West Virginia University, Morgantown.

Kibler, R. J., Cegala, D. J., Miles, D. T., \& Barker, L. L. (1975). Objectives for instruction and evaluation. Boston: Allyn and Bacon. 
McKenzie, L. J. (2002). End of program assessment: An investigation of senior capstone design assessment practices. Unpublished doctoral dissertation, Washington State University, Pullman.

Mintzberg, H. (1979). The professional bureaucracy. In M. C. Brown (Ed.), Organization and governance in higher education (pp. 50-70). Boston: Pearson.

Morreale, S. P., Osborn, M. M., \& Pearson, J. C. (2000).Why communication is important: A rationale for the centrality of the study of communication. Journal of the Association for Communication Administration, 29(1), 1-25.

Morreale, S. P., Rubin, R. B., \& Jones, E. A. (1998). Expectations for speaking and listening for college graduates: Basic and advanced skills. Retrieved April 18, 2005 from http://www.natcom.org/nca/files/ccLibraryFiles/FILENAME/000000000085/College\%20 Competencies.pdf

National Communication Association. (n.d.) About NCA. Retrieved November 25, 2004 from http://www.natcom.org/AboutNCA/about_nca1.htm.

National Communication Association. (n.d) Guidelines for developing a departmental assessment plan. Retrieved April 6, 2005 from http://www.natcom.org/nca/Template2.asp.

National Communication Association (2003). National Communication Association Directory. Washington, DC: NCA.

Newman, F., Couturier, L., \& Scurry, J. (2004). The future of higher education: Rhetoric, reality, and the risks of the market. San Francisco: Jossey-Bass.

Palomba, C. A., \& Banta, T. W. (1999). Assessment essentials. San Francisco: Jossey-Bass. 
Peterson, M. W., \& Einarson, M. K. (2001). What are colleges doing about student assessment? Does it make a difference? The Journal of Higher Education, 72(6), 629-669.

Peterson, M. W., \& Vaughan, D. S. (2002). Promoting academic improvement: Organizational and administrative dynamics that support student assessment. In T. W. Banta (Ed.), Building a scholarship of assessment (pp. 26-48). San Francisco: Jossey-Bass.

Redmond, M.V. (1998). Outcomes assessment and the capstone course in communication. Southern Communication Journal, 64(1), 68-76.

Rice, R. E., Stewart, L. P., \& Hujber, M. (2000). Extending the domain of instructional effectiveness assessment in student evaluations of communication courses. Communication Education, 49(3), 253-266.

Rollman, S. A. (1991, October). Program assessment as a means to improve instruction and enhance faculty development: The first year of assessment of human communication majors at James Madison University. Paper presented at the meeting of the Speech Communication Association, Atlanta, GA.

Shipman, D. (2004). Examining internal programmatic assessments implemented by physician assistant educators. Unpublished doctoral dissertation, West Virginia University, Morgantown.

Suskie, L. (2004). Assessing student learning: A common sense guide. Bolton, MA: Anker.

Shelton, M. W., Lane, D. R., \& Waldhart, E. S. (1999). A review and assessment of national educational trends in communication instruction. Communication Education, 48(3), 228237. 
Wilson, B., \& Plutsky, S. (1999, April). Assessment of the business education program by alumni. Paper presented at the meeting of the American Educational Research Association, Montreal, Quebec. 
Communication Assessment 94

\section{APPENDIX}




\section{Appendix A: Pilot Study Cover Letter}

March 17, 2005

Dear

Thank you for your willingness to participate in the pilot study examining assessment practices in undergraduate programs in communication studies throughout the country.

You are one of 15 communication department chairs participating in this pilot. This study is part of my doctoral dissertation in Educational Leadership Studies at West Virginia University.

Please read the cover letter as if you were participating in the actual study. Then, complete the "Survey of Internal Programmatic Assessments Implemented by Departments of Communication Studies." Please keep track of how many minutes it takes you to complete the entire survey. Feel free to make notes regarding any inconsistencies or problems that you find with the cover letter or survey. I will then schedule a time with you to conduct a short interview so that you can share any suggestions that you might have for improvement. Your input is vital to the success of this research. Thank you for taking the time to participate in this pilot study!

If you have any questions, please feel free to contact me via phone at (304) 293-3905 or via email at $\underline{\text { ACWeber@mail.wvu.edu. }}$

Sincerely,

Andrea C. Weber

WVU Doctoral Candidate 


\section{Appendix B: Pilot Study Interview Questions}

Thank you for taking the time to complete my "Survey of Internal Programmatic Assessments Implemented by Departments of Communication Studies."

Today, I would like to ask you a few questions about the survey to help strengthen it for the actual study with communication studies department chairs.

\section{Cover Letter}

1. Was the purpose of my research clear in the cover letter?

2. Were the potential benefits of the study obvious in the cover letter?

3. Were you motivated to complete the survey after you read the cover letter?

4. Was the cover letter easy to read and understand?

5 . Were the instructions for returning the survey clear?

6. Was anything missing in the cover letter?

\section{Survey}

1. Were the instructions clear on the survey?

2. Were any questions difficult to answer? Why?

3 . Were there any terms that you did not understand?

4. Did the organization of the survey make sense and flow smoothly?

5 . How long did it take you to complete the survey?

6 . Do you have any other suggestions for improvement?

Thank you for your time and effort in this important project! 


\section{Appendix C: Cover Letter to Survey Participants}

\section{Dear Participant:}

I am conducting a study of undergraduate programs in communication studies across the country and I am asking for your participation. The National Communication Association has stressed the necessity of comprehensive program assessment in order to monitor and improve student learning. As there is not one model of ideal assessment, I am interested in studying the actual assessment practices in undergraduate programs in Communication Studies as part of my doctoral dissertation in Educational Leadership Studies at West Virginia University (WVU).

Your input is very important in this study because the results will identify strengths and limitations in assessment practices in undergraduate communication studies programs. The study will allow you to share your current assessment practices so that a baseline of communication studies assessment practices can be established. This baseline will provide useful information for communication studies faculty and administrators to maximize the results of assessment practices. For example, results should yield specific information about the extent to which innovative direct assessment methods are used to enhance Communication Studies curricula. If you are interested, I would be happy to provide you with a summary of the research findings when the study is completed.

Your responses will be confidential since no individual answers will be shared at any time. You do not have to respond to every item on the survey. Your participation in this study is completely voluntary. WVU's Institutional Review Board has approved this study.

- Please complete the enclosed survey.

- The survey is also available online at http://simpleforms.scripts.wvu.edu/sf/CommunicationAssessment/. Please use the code located on the bottom right hand corner of this letter to log on to the web survey.

- Please complete the survey and submit it online or use the self-addressed, stamped envelope to return your survey by November 11, 2005.

Thank you in advance for taking your valuable time to participate in the study. If you have any questions, please contact me at 304-293-3905 or via email at acweber@ mail.wvu.edu.

Sincerely,

Andrea C. Weber

WVU Doctoral Candidate 
Appendix D: Survey Instrument

A Survey of Internal Programmatic Assessments Implemented by Undergraduate Programs in Communication Studies 


\section{A Survey of Internal Programmatic Assessments Implemented by Undergraduate Programs in Communication Studies}

This survey is designed to elicit information about the assessment process within your program. For the purposes of this study, assessment is operationalized as a four step process that includes establishing learning goals, presenting opportunities to achieve these goals, assessing student learning, and implementing assessment findings into the curriculum to improve student learning (Huba \& Freed, 2000).

\section{Undergraduate Departmental Information}

Please indicate the appropriate response for each statement.

Department Title

A. Number of full-time faculty:

B. Number of part-time faculty:

C. Approximate number of full time and part time undergraduate students currently enrolled in your program:

D. Average number of undergraduate students that graduate from your program annually:

E. Is your department a member of National Communication Association? YES NO Eastern Communication Association? YES NO Central States Communication Association? YES NO Southern States Communication Association? YES NO Western States Communication Association? YES NO

Other $\mathrm{regional} / \mathrm{national}$ associations?

Please read each statement below and provide your response. Please mark only one response per statement.

Please select the single statement that best describes the level of development of the assessment plan for your program.

1. The Communication Studies undergraduate program faculty

[ ] has not created an assessment plan.

[ ] is in the beginning stages of developing an assessment plan.

[ ] has developed an assessment plan but has not yet implemented the plan.

[ ] has implemented an assessment plan.

Please complete and return this questionnaire regardless of your answer to this question.

2. The assessment process in my department is

[ ] episodic; it occurs during program review for accreditation purposes only.

[ ] episodic; it occurs as needed for curriculum changes.

[ ] on-going; it is a routine activity used for accreditation purposes only.

[ ] on-going; it is a routine activity used for curriculum changes and accreditation purposes.

[ ] on-going; it is a routine activity used for curriculum changes only. 
Please read the following statements and indicate your response by checking the single most appropriate box with regard to your departmental assessment practices.

\begin{tabular}{|c|c|c|c|c|c|}
\hline & $\begin{array}{c}\text { Every } \\
\text { Semester }\end{array}$ & Once a Year & $\begin{array}{c}\text { Every } 2 \text { to } 3 \\
\text { years }\end{array}$ & $\begin{array}{c}\text { Every } 3 \text { to } 4 \\
\text { years }\end{array}$ & $\begin{array}{c}\text { Every } 5 \\
\text { years or less }\end{array}$ \\
\hline 3. Assessment data are collected. & [ ] & [ ] & [ ] & [ ] & [ ] \\
\hline \multirow[t]{2}{*}{ 4. Assessment data are analyzed. } & [ ] & [ ] & [ ] & [ ] & [ ] \\
\hline & Very Often & Often & Sometimes & Rarely & Never \\
\hline $\begin{array}{l}\text { 5. The assessment process focuses on improving } \\
\text { student learning. }\end{array}$ & [ ] & [ ] & [ ] & [ ] & [ ] \\
\hline $\begin{array}{l}\text { 6. The assessment process focuses on } \\
\text { accountability. }\end{array}$ & {$[\mathrm{l}$} & [ ] & [ ] & [ ] & {[]} \\
\hline
\end{tabular}

Types of Student Learning Outcomes

Please review the following statements and indicate how extensively these learning outcomes are addressed in your program. Please indicate your response by checking the single most appropriate box. These essential skills are identified as student learning outcomes in the Communication Studies program's assessment plan.

Student learning outcomes (SLOs) are what Very Often Often Sometimes Rarely Never your faculty expect students to learn and be able to demonstrate.

7. The student learning outcomes reflect the communication studies program's goals and objectives for learning.

8. The program's student learning outcomes reflect the institution's mission and its values.

9. Our student learning outcomes focus on retrieving relevant knowledge from longterm memory.

10. Our student learning outcomes focus on understanding and constructing meaning from instructional messages; oral, written, and graphic communication.

11. Our student learning outcomes focus on applying and implementing procedures in a given situation.

12. Our student learning outcomes focus on analyzing and breaking material into constituent parts and determine relationship to one another and to an overall structure or purpose. 
Types of Student Learning Outcomes

Please review the following statements and indicate how extensively these learning outcomes are addressed in your program. Please indicate your response by checking the single most appropriate box. These essential skills are identified as student learning outcomes in the Communication Studies program's assessment plan.

Student learning outcomes (SLOs) are what Very Often Often Sometimes Rarely Never your faculty expect students to learn and be able to demonstrate.

13. Our student learning outcomes focus on evaluating and making judgments based on criteria and standards.

14. Our student learning outcomes focus on [ ] [ ] [ ] [ ] creating and putting elements together to form a coherent or functional whole; reorganize elements into a new pattern or structure.

15. Our student learning outcomes focus on affective dimensions (attitudes, values, emotions).

16. Our student learning outcomes focus on psychomotor dimensions (skills, performance abilities).

Please review the following statements and indicate your response by checking the appropriate box with regard to your departmental assessment practices.

\begin{tabular}{|lccccc|}
\hline $\begin{array}{l}\text { Student learning outcomes are what your faculty } \\
\text { expect students to learn and be able to } \\
\text { demonstrate. }\end{array}$ & $\begin{array}{l}\text { Very } \\
\text { Often }\end{array}$ & Often & Sometimes & Rarely & Never \\
$\begin{array}{l}\text { 17. Our student learning outcomes are developed } \\
\text { in accordance with our program mission }\end{array}$ & [ [ ] & [ [ ] & [ ] & [ ] & [ ]
\end{tabular}

statement.

18. Our student learning outcomes are clear.

19. Our student learning outcomes are shared with faculty.

20. Our student learning outcomes are shared with students. 


\section{Characteristics of Student Learning Outcomes}

Please read the following statements and indicate your response by checking the single most appropriate box based on your departmental assessment practices.

Student learning outcomes are what your faculty $\quad$ Very Often $\quad$ Often $\quad$ Sometimes Rarely Never expect students to learn and be able to demonstrate.

21. Students are informed of intended student learning outcomes upon entering the program.

22. Students are informed of intended learning outcomes throughout the program.

23. Students are aware of intended learning outcomes upon graduation.

24. Our student learning outcomes are

developed in collaboration with other faculty.

[ ] [ ]

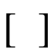

[ ]

[ ]

25. Our student learning outcomes are fully implemented into our curriculum.

26. Our student learning outcomes focus on skills/abilities central to the discipline.

27. Students are provided multiple ways of demonstrating each intended learning outcome across the curriculum.

28. Multiple teaching methods are utilized to assist students in achieving intended learning outcomes.

29. The learning outcomes of individual courses reinforce the program-level outcomes.

30. The program curriculum is a "set of interrelated courses and experiences" designed to help students to achieve intended learning outcomes. 
31. Assessment activities at the department level are conducted at these points in the students' program of study: (Please check all that apply.)

[ ] Freshman year [ ] Sophomore year [ ] Junior year [ ] Senior year [ ] Post-graduate

Please indicate the frequency of direct and indirect methods used to assess student learning at the department level.

$\begin{array}{lcccccc}\text { Direct Methods } & \text { Freshmen } & \text { Sophomore } & \text { Junior } & \text { Senior } & \text { All } & \begin{array}{c}\text { Not } \\ \text { applicable }\end{array} \\ \text { Please check all that apply. } & \text { Year } & \text { Year } & \text { Year } & \text { Year } & & \text { pear }\end{array}$

\section{Student Portfolios}

33. Course-Embedded Assignment

[ ]

[ ]

[ ]

[ ]

[ ]

34. Capstone Projects

35. Juried Reviews of Student Projects

36. Case Studies

37. Internships

38. Essays

39. Faculty Designed Tests

40. Standardized Tests

41. Other

\begin{tabular}{|c|c|c|c|c|c|}
\hline $\begin{array}{l}\text { Indirect Methods } \\
\text { Please check only one box per }\end{array}$ & $\begin{array}{l}\text { Every } \\
\text { Semester }\end{array}$ & $\begin{array}{l}\text { Once a } \\
\text { Year }\end{array}$ & $\begin{array}{l}\text { Every } 2 \text { to } \\
3 \text { years }\end{array}$ & $\begin{array}{l}\text { Every } 3 \text { to } \\
4 \text { years }\end{array}$ & $\begin{array}{l}\text { Every } 5-6 \\
\text { years }\end{array}$ \\
\hline
\end{tabular}
question.

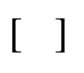

[]

[ ]

[ ]

[ ]

[ ]

[ ]

[ ]

[ ]

[ ]

[ ]

[ ]

[ ]

[ ]

[ ]

[ ]

[ ]

[ ]

[

[ ]

[ ]

[ ]

[ ]

[ ]

[ ]

[ ]

[ ]

[ ]

[ ]

[ ]

42. Alumni Surveys

[

43. Student Surveys

44. Employer Surveys

45. Focus Groups

46. Exit Interviews

47. Reflection Papers
[ ]

[ ]

[ ]

[ ]

[ ]
[ ]

[ ]

[ ]

[ ]

[ ]

[ ]
[ ]

[ ]

[ ]

[ ]

[ ]

[ ]
[ ]

[ ]

[ ]

[ ]

[ ]

[ ]
[ ]

[ ]

[ ]

[ ]

[ ]

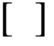

[ ]

48. Other 
Assessment Results

Please indicate how assessment results are used at the department level. Please check one box for each item.

Assessment results are used for:

Very Often Often Sometimes Rarely Never

49. Curricular changes.

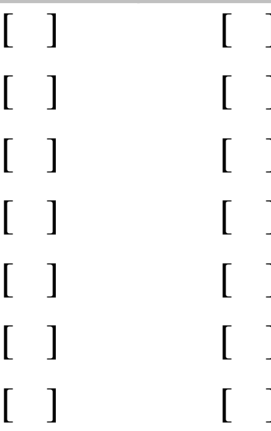

[ ]
$[$ ]
$[$ ]
$[$ ]
[ ]
$[$ ]
$[$ ]

50. Resource allocation.

51. Program planning and decision-making.

52. Program review.

53. Student recruitment.

54. Improving student learning.

55. Evaluation of the assessment process.

56. Other

Assessment Audiences

Please indicate the groups or individuals that receive assessment reports. Please check one box per item.

\begin{tabular}{|c|c|c|c|c|c|}
\hline Assessment data is reported to: & Very Often & Often & Sometimes & Rarely & Never \\
\hline 57. Students. & [ ] & [ ] & [ ] & [ ] & [ ] \\
\hline 58. Faculty. & [ ] & [ ] & [ ] & [ ] & [ ] \\
\hline 59. Administrators. & [ ] & [ ] & [ ] & [ ] & [ ] \\
\hline 60. Governing Board. & [ ] & [ ] & [ ] & [ ] & [ ] \\
\hline 61. Parents. & [ ] & [ ] & [ ] & [ ] & [ ] \\
\hline 62. Accrediting Organizations. & [ ] & [ ] & [ ] & [ ] & [ ] \\
\hline 63. General Public. & [ ] & [ ] & [ ] & [ ] & [ ] \\
\hline 64. Alumni Organizations. & [ ] & {[]} & [ ] & [ ] & [ ] \\
\hline
\end{tabular}

65. Other

Dissemination of Assessment Results

Please indicate the methods used to disseminate departmental assessment results and how extensively they are used. Please check one box per item.

\begin{tabular}{|c|c|c|c|c|c|}
\hline The program disseminates assessment results via: & Very Often & Often & Sometimes & Rarely & Never \\
\hline 66. School newspaper. & [ ] & [ ] & [ ] & [ ] & [ ] \\
\hline 67. Accrediting organization reports. & [ ] & [ ] & [ ] & [ ] & [ ] \\
\hline 68. Governance board reports. & [ ] & [ ] & [ ] & [ ] & [ ] \\
\hline 69. Marketing campaigns. & [ ] & [ ] & [ ] & [ ] & [ ] \\
\hline 70. Institution's website postings. & [ ] & [ ] & [ ] & [ ] & [ ] \\
\hline 71. Institution's catalog and brochures. & [ ] & [ ] & [ ] & [ ] & [ ] \\
\hline 72. Conference presentations and workshops. & [ ] & [ ] & [ ] & [ ] & [ ] \\
\hline
\end{tabular}

73. Other: 
Please indicate the extent to which you agree with the following statements. Please check one box per item.

74. Our assessment effort has administrative-level Very Often Often Sometimes Rarely Never support.

75. Our program has articulated projected resource expenditures for assessment to administrators.

76. Our administrators have allocated resources for initial assessment costs.

77. Our administrators have allocated resources to implement and sustain assessment.

[ ] [

[ ]

[ ]

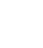

78. Our institutional leaders provide an assessment culture characterized by the following:

(Please mark all that apply)

[ ] Meeting regularly with assessment personnel.

[ ] Maximizing honest, open, two-way communication between department and administration.

[ ]Establishing an environment based on trust.

[ ] Treating faculty, staff, and administrators as collaborators in a team effort.

[ ] Demonstrating a commitment to assessment by providing real incentives for faculty participation and support (e.g., time, teaching loads, grants, stipends, students).

[ ] Encouraging assessment personnel to use a deliberate planning process.

[ ] Encouraging slow, incremental changes thereby increasing chances for success.

[ ] Approving the integration of assessment and budget.

OTHER:

\section{Faculty Development}

Please indicate the frequency of the following in your department. Please check one box per item.

$\begin{array}{cccccc}\text { Monthly } & \text { Quarterly } & \begin{array}{c}\text { Bi- } \\ \text { annually }\end{array} & \text { Yearly } & \begin{array}{c}\text { Every 2 } \\ \text { years or } \\ \text { less }\end{array} & \text { Never } \\ \text { [ ] } & {[\text { [ ] }} & \text { [ ] } & \text { [ ] } & \text { [ ] } & \text { [ ] }\end{array}$

79. On-c.
sessions.

80. Off-campus experts teach our assessment sessions.

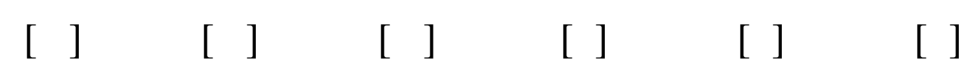

During the last academic year, how often have these types of assessment sessions been attended by one or more members of your departmental faculty?

(Please mark all that apply)

81. Formal presentations.

82. Hands-on, interactive, single topic workshops.

83. Hands-on, interactive, multi-topic workshops.

84. Other 
85. Our departmental faculty development sessions have addressed: (Please mark all that apply)

[ ] Assessment philosophy.

[ ] Assessment language.

[ ] Gaining institutional resources.

[ ] Faculty development \& assessment.

[ ] Student learning outcomes.

[ ] Instruments for measuring learning.

[ ] Using assessment results to affect change.

[ ] Reporting assessment results.

[ ] Other:

86. During the last academic year, how many of your faculty have attended faculty development sessions on assessment?

Explain if necessary:

Faculty Incentives for Assessment

Please indicate how frequently each incentive is provided to your faculty. Please check one box per item.

87. Time.

Every

Once a Year Every 2 to 3 years Every 3 to 4

Every 5-6 Semester years

88. Small grants (less than \$2000). 89. Large grants (\$2000 or more).

90. Graduate assistant.

91. Travel to other institutions.

92. Stipends.

93. Travel to assessment conferences. [ ]

[ ]

\section{[ ]}

[ ]

[ ]

[ ]

[ ]

[ ]

[ ]

[]

[ ]

[ ]

[ ]

[ ]

[ ]

[ ]

[ ]

[ ]

[ ]

[ ]

[]

[ ]

[ ]
years

94. Other:

95. During the last academic year, how many of your faculty have received these incentives? 
Faculty Benefits for Assessment

Please indicate how extensively each incentive is provided to your department faculty as a reward for assessment efforts.

Please check one box per item.

\section{BENEFITS}

96. Increased interaction with other faculty

members.

97. Increased interaction with faculty members from other institutions.

98. Increased understanding of institutional

linkages.

99. Knowing that assessment results will not be used against them.

100. Letters of commendation for personal files.

101. Public expressions of gratitude from institutional leaders.

102. Publication of assessment results in journals and books.

103. Presentations at national conferences.

104. Inclusion of participation in the promotion and tenure process.

105. Personal expressions of gratitude from institutional leaders.

$\begin{gathered}\text { Very } \\ \text { Often }\end{gathered}$ Often Sometimes Rarely Never
D

$\left[\begin{array}{lllll}] & {[} & {[} & {[} & {[}\end{array}\right]$

$\left[\begin{array}{lllll} & ] & {[} & {[} & {[}\end{array}\right]$

[

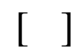

[ ]

[ ]

[ ]

[]

[ ]

[ ]

[ ]

[ ]

[

[ ]

[ ]

[]

[]

[

[ ]

[ ]

[ ]

[ ]

[

[ ]

[]

[]

[]

[

[

[ ]

[ ]

[ ]

106. Other:

Please return the completed survey in the enclosed stamped envelope.

If you have any questions or comments you may contact:

Andrea Weber

West Virginia University

Department of Communication Studies

PO Box 6293

Morgantown, WV 26506-6293

304-293-3905 (Office Hours 8:30-4:30 Monday through Friday)

This survey is confidential. Your name and institution will not be revealed. Your participation is greatly appreciated. Thank you. 